\title{
Review on the rocking wall systems as a self-centering mechanism and its interaction with floor diaphragm in precast concrete structures
}

\author{
Mohd Asha'ari Masrom ${ }^{a *}$ (D), Nor Hayati Abdul Hamid ${ }^{b}$ \\ a Faculty of Civil Engineering, Universiti Teknologi MARA Cawangan Pulau Pinang, 13500 Permatang Pauh, Penang, Malaysia. \\ E-mail: ashaarimasrom@uitm.edu.my \\ b Institute for Infrastructure Engineering Sustainable and Management (IIESM), Universiti Teknologi MARA, 40450 Shah Alam, Selangor, \\ Malaysia. E-mail: norha454@uitm.edu.my \\ * Corresponding author
}

http://dx.doi.org/10.1590/1679-78256115

\begin{abstract}
The severe damage of precast concrete wall structures that have been recorded in the past earthquake has led to the innovation of the rocking wall concept which can demonstrate free or minimum damage aftershock of an earthquake. Furthermore, extensive research works have been well conducted in the past three decades on the establishment of precast rocking wall systems, designs, details, and techniques. Despite this extensive development, little attention has been devoted to investigate the interaction between the rocking wall systems and the flooring diaphragm. The historical perspective on the development of rocking wall systems over the past few decades in the precast concrete structures is presented. Subsequently, the limited research works on the interaction of precast rocking wall to the floor diaphragm are described. Apart from that, this paper attempts to highlight the application of rocking wall systems in the context of precast connection for the precast load-bearing structures. In this contribution, the precast rocking wall-floor connection for precast load-bearing structures is proposed and presented in this paper.
\end{abstract}

\section{Keywords}

energy dissipation, load-bearing structures, precast concrete connection, rocking wall system, self-centering

\section{Graphical Abstract}

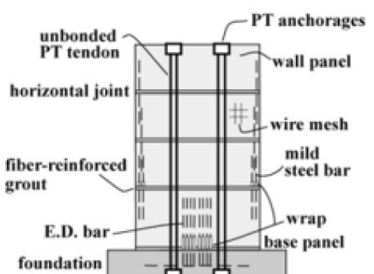

elevation

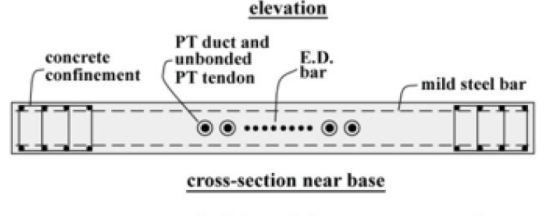

Precast Hybrid wall (Kurama 2002).



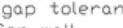
for wall M16x2.0p hex

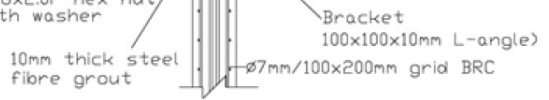

Proposed precast connection detail between the rocking wall system and precast floor plank. 


\section{INTRODUCTION}

According to the $\mathrm{ACl} 318$ (Chapter 21), two alternatives for construction of precast concrete buildings under seismic regions which is emulative and non-emulative design are permitted ( $\mathrm{ACl}$ 318-11, 2011). The emulative design is referred to the behavior of a precast building system which is expected to behave similarly with an equivalent monolithic system. The basic principle of this design philosophy which is also well-known as "capacity design" or the hierarchy of strength has been developed by Professor Bob Park and Professor Tom Paulay around the 1960s. This design is to ensure that the "weakest link of the chain" in the structural system is positioned where the designer intended to behave as a ductile "fuse" and prevent the structure from undesired brittle failure mechanisms. In this respect, the emulative approach in the precast concrete wall is intentionally designed to dissipate seismic energy through inelastic behavior of structural elements. The inelastic response is purposely concentrated at the base of the wall regions of the structure which is known as the plastic hinge regions (PHZ). Predominantly, the energies are dissipated through the yielding of reinforcing steel and crushing of concrete. All of these energy dissipation mechanisms are associated with damage to structural elements. The development of inelastic action in emulative connections has been assumed to inevitably lead to structural damage, thus indicating that "ductility = damage", with associated repair costs and business downtime (Pampanin 2012). Thus, the emulation concept does not fully utilize the unique properties of precast concrete in seismic design of buildings structures and this alternative will not result in the efficiency of precast systems.

In contradiction, the non-emulative design philosophy is referred to allow joints between precast members to undergo inelastic deformations without significant damage. Several non-emulative design approaches such as Performance-Based Earthquake Engineering developed by Priestley (2002) and Damage Avoidance Design (DAD) proposed by Mander and Cheng (1997). The objectives of these designs are to minimize damage, reduce economic losses due to downtime, prevent collapse, and ensuring life safety of the structures under Design Basis Earthquake (DBE) and Maximum Considered Earthquake (MCE). Thus, the displacement-based performance design is fully adopted in construction industries to improve residual drift control, define performance level together with damage limit state. In relation with this design, the idea and innovation of design and constructing rocking wall system under damage-control design philosophy can improve the overall seismic performance of precast structures. The ductility-damage equivalency is not anymore, a necessary compromise of a ductile design in this approach as the previous approach (Capacity design). Using the unbonded post-tensioning at the center of precast concrete walls can prevent the collapse of the structures through a self-centering mechanism which exhibit elastic behavior by helping them to mitigate the sustained damage. This type of wall is known as rocking wall which is not connected rigidly to the foundation beam and allows discontinuous between the bottom of the wall and foundation. When the rocking wall is subjected to lateral loads, it rocks about the corners causing a separation at the interface initiating at the opposite corner and the strands provide a restoring force to self-centering in the walls. Furthermore, by inhibiting the yielding and elongation over their total length of strands cause the gap opening and avoid the formation of the plastic hinge zone.

Although tremendous research progress has been made towards the rocking wall system for precast concrete in high seismic regions, yet, only a few research studies were conducted on the interaction between the rocking wall and the floor diaphragm action. This less effort has led to the relatively slow practical adoption of the rocking wall systems on the precast concrete structures. Indeed, general research in the rocking wall to floor connection is still in its infancy. In this respect, this paper presents extensively on development of a rocking wall system and the interaction of this wall system to floor diaphragm. In addition, further application of this wall system into the precast load-bearing structures is also presented.

\section{DEVELOPMENT OF SELF-CENTERING SYSTEM IN PRECAST CONCRETE SHEAR WALL}

A lot of research work have been conducted on the development of precast emulative connections under seismic loads by ensuring that the seismic behavior of precast structures would be comparable to equivalent monolithic cast-inplace reinforced concrete structures. The ACl Committee, (2001) produced a guideline for engineers to provide the precast concrete detailing which meet the building code requirements (ACl 318-99, 1999) in all seismic regions by emulating cast-in-place reinforced concrete design. An alternative to emulative approach, a non-emulative concept was introduced in precast connections for critical regions by using unbonded post-tensioned precast concrete wall system. This concept was inspired by Priestley and Tao (1993) who proposed the precast building frames with the idea of using the post-tensioning to provide an improved restoring force. The connection concept could take advantage of the unique properties of precast concrete and offers better-performing structures than do comparable alternatives. Thus, the rocking precast wall systems have been invented and established by many researchers in the form of a single rocking 
wall, precast concrete jointed wall, hybrid wall and precast wall with end columns (PreWEC). The historical development of these rocking wall systems is further discussed in the subsequent paragraph.

In response to an organized need to construct seismic-resilient precast structures, the systematic study on the rocking wall system has been initiated by Priestley (1991) in the Precast Seismic Structural System (PRESSS) program. The program featured both experimental and theoretical studies of rocking systems in the precast concrete frame building. This program aims to develop a new design concept, innovative materials and technologies for precast concrete construction in different seismic zones. In addition to these investigations undertaken on self-centering prestressed frame connections during the PRESSS program, researchers analytically investigated this concept for application to precast concrete walls, leading to the development of unbonded post-tensioned precast concrete rocking walls (Kurama et al. 1999). The jointed wall concept comprises of individual walls that are anchored to the foundation using unbonded post-tensioning, with stainless steel U-shaped connectors placed between the walls for added energy dissipation as depicted in Figure 1.

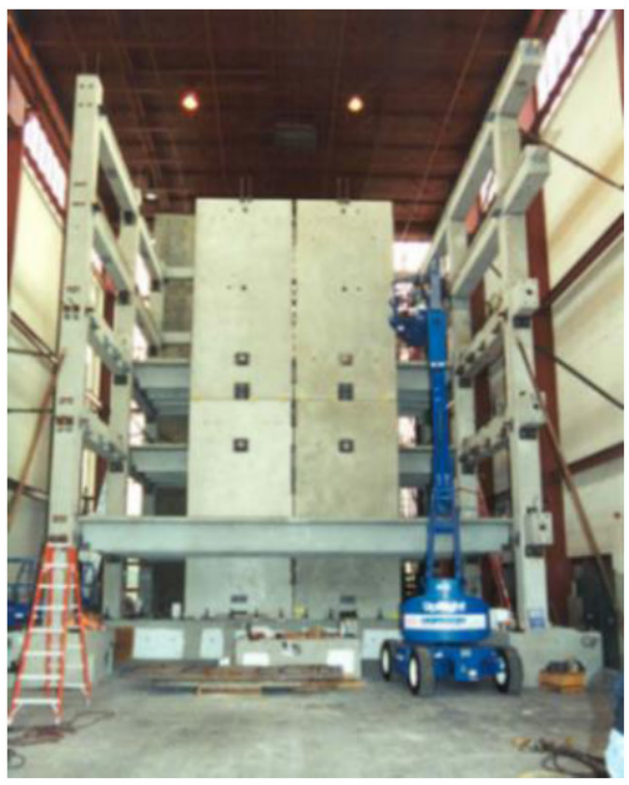

(a)



(b)

Figure 1 (a) The PRESSS building after erecting the wall system (b) Elevation view of the jointed wall system in the PRESSS test building (Priestley et al. 1999).

The unbonded post-tensioning is designed to re-center the wall system when the load is removed so there will be no residual drift after a design-level of the earthquake. It has exhibited that all the features that it was intended to possess under design loading: zero residual drift, closely predictable peak drift, and minimal damage. The damage is minor in extent and could be repaired easily. These excellent attributes were inspired and spurred many researchers to further explore the potential of the rocking system in the precast concrete wall structures. Subsequently, numerous experiment studies related to rocking-wall systems had been conducted since then. After the first developments and significant refinement in PRESSS program, the study was extended and encompassed various configurations of the precast wall panels as depicted in Figure 2. 


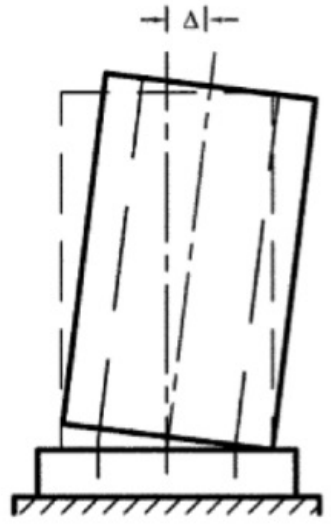

(a)



(b)

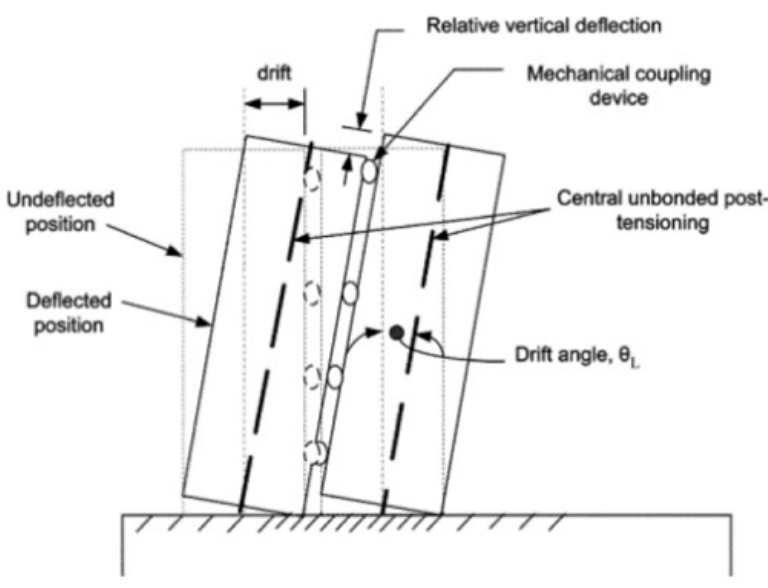

(c)

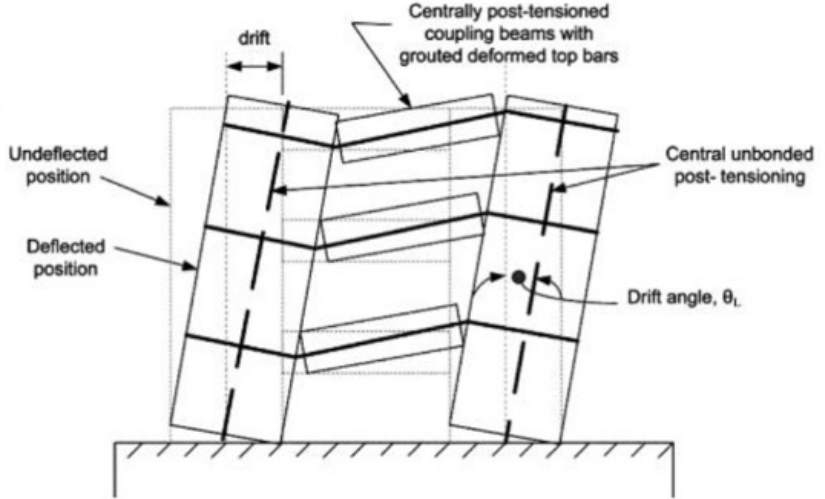

(d)

Figure 2 Precast walls: (a) single panel wall (b) multi-panel wall (c) coupled wall with the vertical joint (d) coupled wall with coupling beams (ACI ITG-5.1-07 2007).

In the early work of rocking wall system, various efforts have been put into the investigation on the usage of uncoupled (single panel) precast walls featuring gap opening across horizontal connections using only unbonded PT (post-tensioned) steel (Kurama et al. 1999; Perez et al., 2002; Holden et al. 2003; Perez et al. 2007; Erkmen and Schultz 2009; Henry et al. 2011; Belleri et al. 2014a). From these studies, they discovered that the rocking walls display a nonlinear elastic response with essentially no energy dissipation capacity, suffer from excessive uplift, shear slip, and lateral strength and stiffness degradation due to the accumulation of plastic tensile strains in the connection reinforcement under reversed-cyclic loading. The low energy-dissipation capacity associated with large displacement has noticed by merely relying on unbonded PT connections. The walls were conceived to have relatively little energy dissipation because their PT tendons were designed not to yield during a design-level earthquake event. This, however, led to uncertainties associated with their possibly unreliable performance in high seismicity areas. When realizing those weaknesses, Kurama has (2002) carried an experiment to investigate the uses of mild steel reinforcement in addition to the post-tensioning steel for flexural strength and inelastic energy dissipation. The mild steel reinforcement is designed to yield in tension and compression, providing energy dissipation. Figure 3 shows an example of the precast hybrid wall specimen constructed by Kurama (2002) using unbonded PT bar and bonded mild steel bar as energy dissipator. 

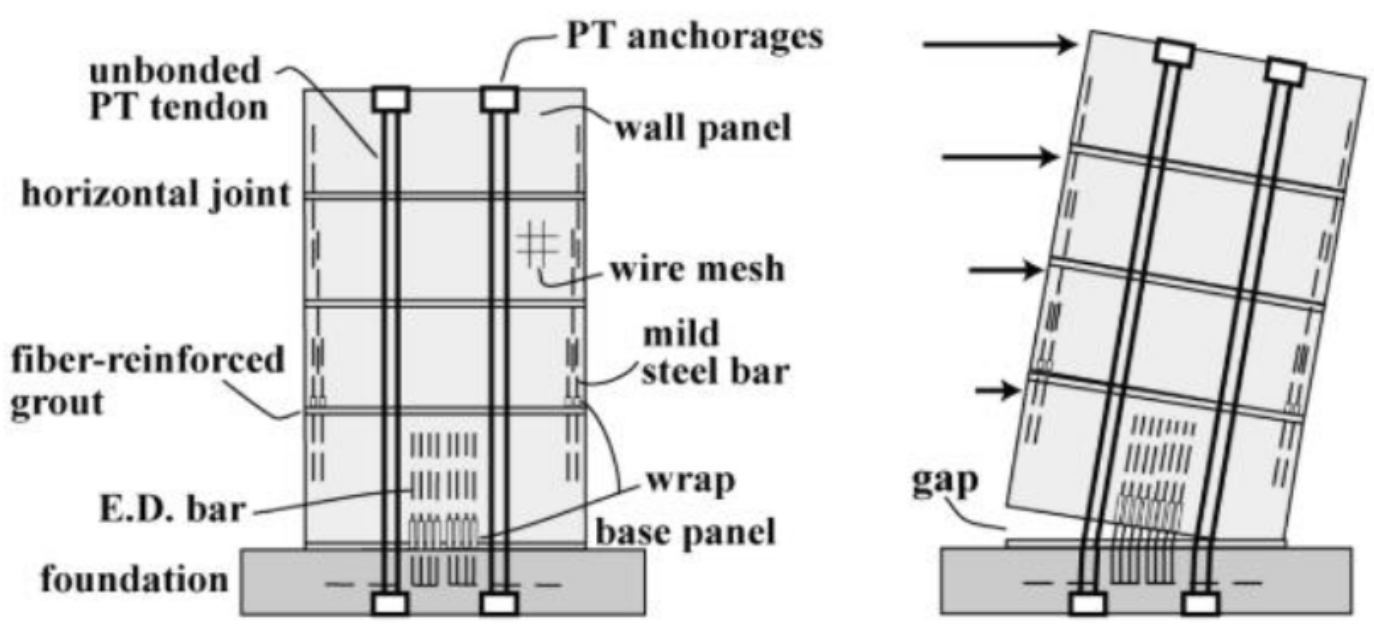

\section{elevation}

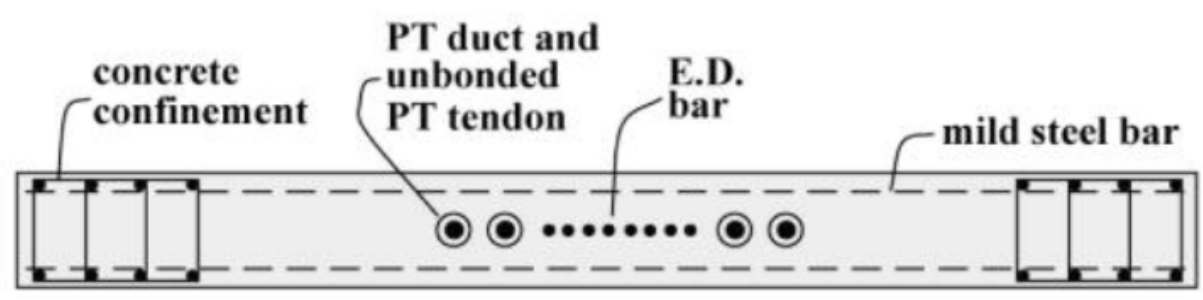

\section{cross-section near base}

Figure 3 Precast Hybrid wall (Kurama 2002).

Based on the experimental work, the use of mild steel reinforcement as energy dissipator (E.D) decreased the maximum lateral displacement and the number of large-displacement peaks of the wall for regions with high seismicity. Besides that, the reduction in the maximum displacements is nearly proportional to the amount of mild steel. This relationship is depicted in Figure 4 based on four six-story hybrid precast walls (PH6, HH6-25, HH6-50 and HH6-75) and the emulative wall (EH6). The hybrid walls HH6-25, HH6-50, and HH6-75 have, approximately, 0.25, 0.50, and 0.75 times, respectively, the amount of mild steel reinforcement used in the emulative wall EH6 for a region with high seismicity. The amount of post-tensioning steel used in the hybrid walls was determined so as to result in similar flexural strengths as wall PH6 for regions with high seismicity. The vertical axis in this figure shows the maximum roof drift of the six-story prototype walls in regions with high seismicity, $\Delta_{m}$, divided by the maximum roof drift of the unbonded post-tensioned wall PH6, $\Delta_{\mathrm{mp}}$. This ratio is referred to as $r_{\mathrm{dp}}=\Delta_{\mathrm{m}} / \Delta_{\mathrm{mp}}$. Meanwhile, the horizontal axis in the figure represents the mild steel ratio of the walls, $\rho_{s}$, divided by the mild steel ratio of the emulative Wall EH6, $\rho_{s e}$, referred to as $r_{s e}=\rho_{s} / \rho_{s e}$. Each data marker $(\diamond)$ in the figure denotes the $r_{d p}$ value for a wall determined using one ground motion and the thick dashed red line shows the average value, $\overline{\mathrm{r}}_{\mathrm{dp}}$, considering the seven MIV-scaled Northridge-Sylmar (NOSY) ground motion used in the dynamic analyses of the walls.



Figure 4 Normalized maximum roof drift for the six-story walls in regions with high seismicity (Kurama 2002). 
Apparently, the relationship between $\overline{\mathrm{r}}_{\mathrm{dp}}$ and $\mathrm{r}_{\mathrm{se}}$ is close to linear, indicating that the reduction in the maximum roof drift is, on average, nearly proportional to the amount of mild steel. Several researchers (Rahman and Restrepo 2000; Holden 2001; Restrepo and Rahman 2007; Smith et al. 2011,2013) have also investigated extensively a similar study. The general result, reflecting the maximum displacements to the amount of mild steel, is similar to those reported by Kurama (2002). Principally, the hybrid wall system is designed to attain a stable flag-shaped hysteretic response. The dissipative and re-centering mechanism of a hybrid system is portrayed by a "flag-shape" hysteresis behavior as shown in Figure 5. The combination of the self-centering mechanism from unbonded post-tensioned tendons and energy dissipation from mild steel leads to the formation of the 'flag-shape' hysteresis loop in the hybrid system.

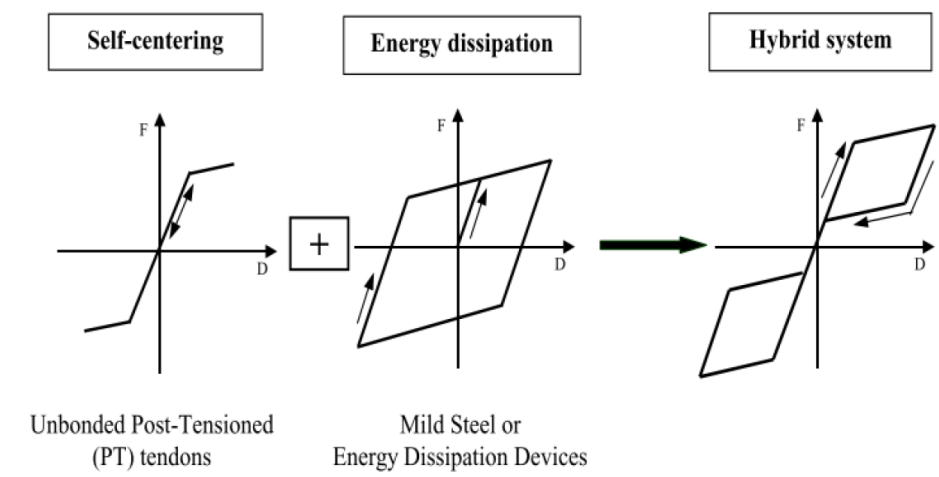

Figure 5 Flag-shape hysteresis loop for a hybrid system (modified after (fib 2003)).

The relative amount of these post-tensioned tendons and energy dissipating devices used in a hybrid wall system can be measured using a parameter, $k_{d}$, which is referred to as the E.D steel moment ratio (Kurama 2005) defined by Equation (1)

$k_{d}=\frac{M_{w s}}{M_{w p}+M_{w g}}$

where $M_{\mathrm{wp}}=$ moment provided by initial effective PT force; $M_{\mathrm{wg}}=$ moment provided by the applied (external) axial load; $M_{\text {ws }}=$ maximum moment provided by the energy dissipating elements. The numerator and denominator in the equation are referring to the energy dissipation and the self-centering term respectively. The properties and shape of this "flagshape" can be modified by varying the (moment) contributions, between the re-centering and the dissipation components as illustrated in Figure 6.



Figure 6 Effects of varying the ratio between re-centering (denominator, post-tensioning and axial load) vs. dissipative (numerator, mild steel and dissipaters) contribution to the Flag-Shape Hysteresis loop (modified after Nakaki et. al 1999).

An appropriate value for $k_{d}$ should be carefully chosen for the design. If $k_{d}$ is too small, the energy dissipation of the wall may be very small. On the contrary, if $k_{d}$ is too large, the self- centering capability of the wall may not be sufficient to yield the tensile E.D. bars back in compression and close the gap at the base joint upon the removal of lateral loads. 
In this regard, Smith and Kurama (2012) have suggested that the $k_{d}$ ratio used in the design should not exceed 0.80 to ensure sufficient self-centering and should not be less than 0.50 to ensure sufficient energy dissipation.

The broken energy dissipator bars embedded in the concrete wall aftershocks had led to several researchers (Kurama 2000; Ajrab et al. 2004; Restrepo and Rahman 2007; Marriott et al. 2008; Twigden et al. 2017) to innovate different configurations of external energy dissipators in precast rocking walls such as special supplemental energy dissipation devices. This permitted the dissipation devices to be simply replaced or inspected following a major earthquake. Figure 7 demonstrates an example of the post-tensioned precast rocking wall which is mounted with external mild steel dampers.
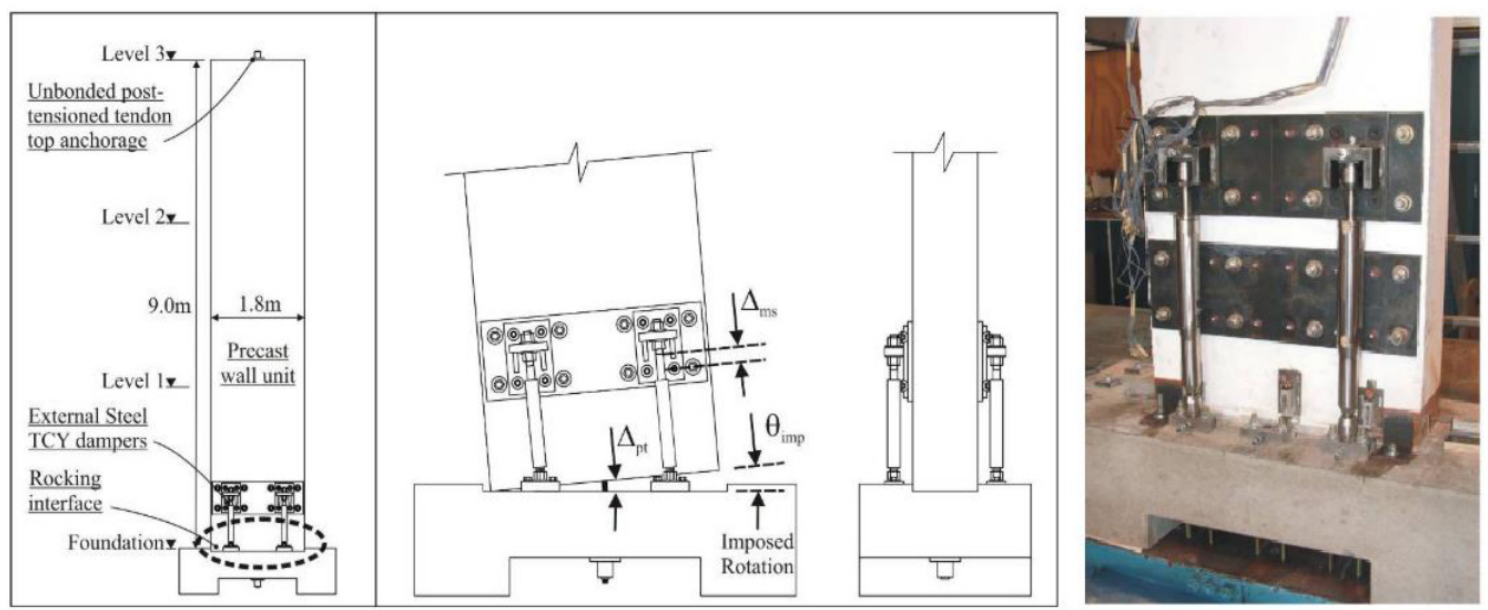

Figure 7 Post-tensioned precast rocking wall system with externally mounted mild steel dampers (Marriott et al. 2008).

Despite the successful establishment of rocking concept in jointed wall system by Priestley et al. (1999), this particular wall system has not been gaining an intention for the seismic resistance application in the precast structure since the concept was proven more than a decade ago. According to Sritharan et al. (2015), they have been identified as the causes for two reasons: 1) the moment resistance of the wall system is less than an equivalent cast-in-place wall; and 2) despite having performed satisfactorily, the stainless steel U-shaped connectors are expensive and their behavior is difficult to predict due to strain history-dependent hardening. They claimed that the reduction in the moment resistance of the jointed wall system is primarily attributed to the reduction in lever arm associated with dividing the wall into several separate panels. Subsequently, Sritharan et al. (2008) have introduced a new wall concept known as Precast Concrete Wall with End Columns (PreWEC) followed by the performance verification works by Aaleti and Sritharan (2009). Figure 8 shows the usage of ductile vertical joint connections (known as O-connector) located along both sides of the wall panel. This O-connector is intentionally designed to yield or slip during wall rocking and promote the easy replacement of the energy dissipating components if needed after an earthquake. The uplift at the wall-to-foundation interface was allowed to return to the initial position, and energy dissipating O-connectors were used to dissipate the seismic energy. The experimental validation of the O-connectors was conducted by Henry et al. (2008). 


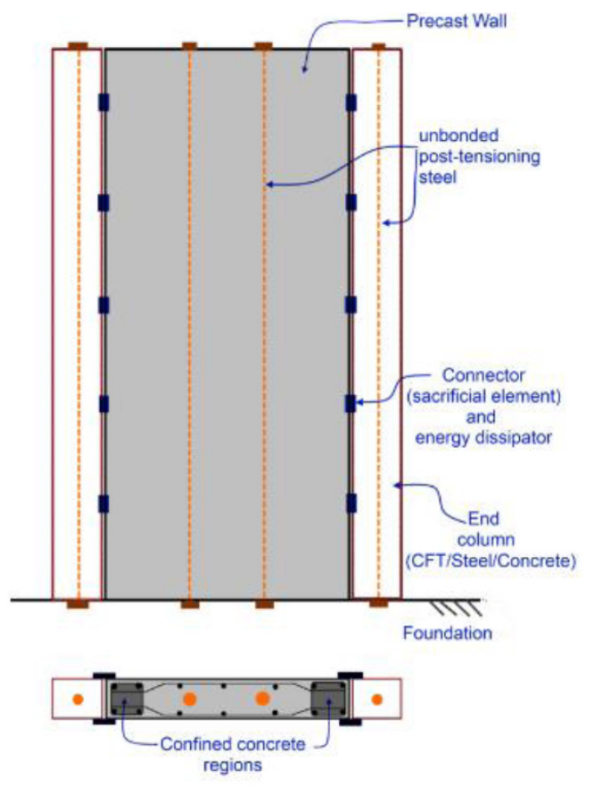

(a)

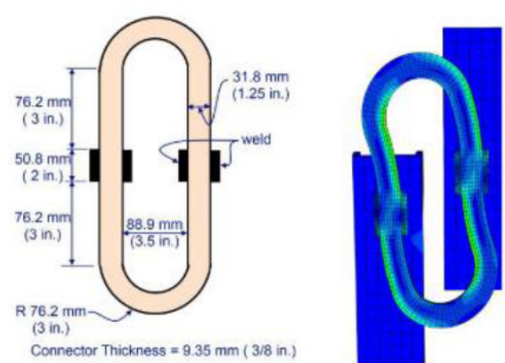

(b)

Figure 8 Precast wall with end columns (PreWEC) system (a) Wall Configuration (b) Energy dissipator (O-connector with the deformed shape) (Sritharan et al. 2015).

In the same manner, other researchers (Perez et al. 2004a; Aaleti and Sritharan 2009; Guo et al. 2014; Rahman and Sritharan 2015; Twigden et al. 2017) also investigated the coupled walls, vertically jointed walls with the adjustable energy-dissipating coupling details. Figure 9 shows the self-centering precast wall panel system using friction device between the wall and adjacent columns which proposed by Guo et al. (2014).

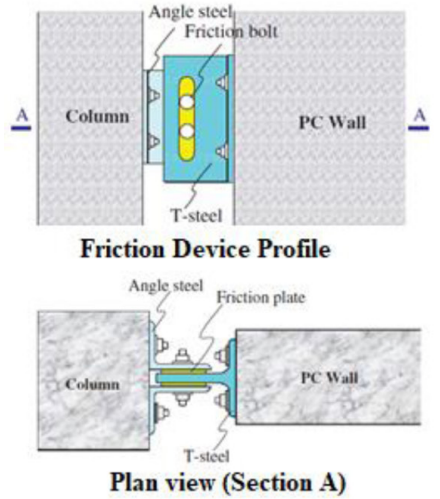

(a)

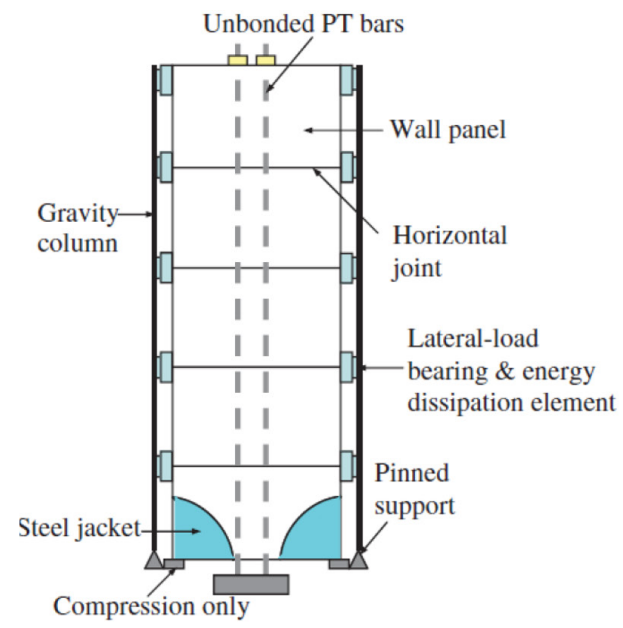

(b)

Figure 9 Self-centering precast concrete (SCPC) wall system (a) Friction device (b) SCPC wall with its adjacent columns (Guo et al. 2014).

Weldon \& Kurama $(2007,2010,2012)$ focused on investigating the behavior and design of unbonded PT precast coupling beams for coupled walls. They utilized the unbonded post-tensioned tendon under lateral loads associated with the steel angle at top and bottom of the precast coupling beam as shown in Figure 10. In this experiment, they observed the effects of design parameters, such as the amount of post-tensioning, beam and wall properties, and top and seat angle properties, on the lateral strength and displacement characteristics of floor-level coupling beam subassemblies. The nonlinear displacements of unbonded post-tensioned coupling beams are governed by the opening of gaps at the beam-to-wall joints. Steel top and seat angles are used at the beam end to yield and provide energy dissipation. The experimental works were validated using analytical modeling. 


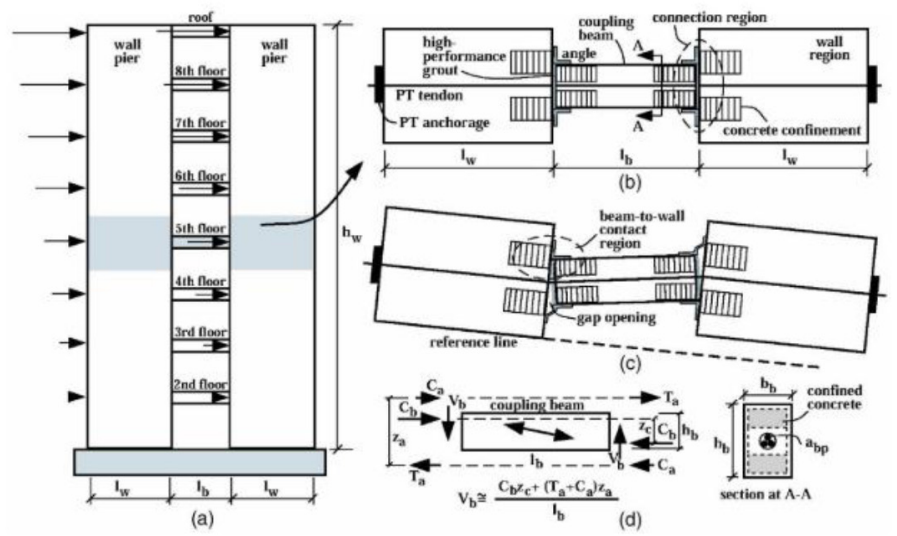

Figure 10 Coupled wall system: (a) multistory wall (b) subassembly (c) idealized displaced shape and (d) beam free-body diagram deformations (Weldon and Kurama 2007).

Besides that, several researchers (Holden et al. 2003; Preti and Giuriani 2012; Smith et al. 2011, 2013; Gavridou et al. 2014; Pakiding et al., 2015; Zhu and Guo 2017; Lu and Wu 2017; Gu et al. 2019) made some comparison of seismic performance between the conventional precast wall (emulative) and precast hybrid wall system (non-emulative) in term of hysteresis loops, energy dissipation, lateral strength, initial construction cost, economic losses and others. In common, the results show that the precast hybrid walls feature minimal structural damage, superior restoring, energy dissipation, ductile behavior and excellent self-centering tendency over larger lateral displacements compared to their reinforced concrete (RC) counterpart. The hybrid wall is a reliable and cost-effective option for the lateral-force resisting system where the economic losses in the building can be further reduced, resulting in a nearly damage-free building under Maximum Considered Earthquake (MCE) event.

The design guidelines for unbonded post-tensioned in rocking wall structures entail that the strands remain essentially linear-elastic under the Design Basis Earthquake (DBE) and significant post-yield strand stresses can develop under the Maximum Considered Earthquake (MCE). The use of unbonded post-tensioning for seismic resistance might cause the anchorage regions under extreme demands where premature strand wire fractures can take place. The yielding and fracture behavior of PT strand systems is a primary source of the collapse behavior of self-centering systems. In other words, the sudden drops in the axial tensile resistance of mono strand-anchor systems can jeopardize the rocking wall system. In this regard, some researchers (Walsh and Kurama 2008,2009; Sideris et al. 2014; Bruce and Eatherton 2016; Yang and Okumus 2017) have conducted studies related to anchorage issues in the unbonded post-tensioned system. The works investigated include seating losses, deformation capacity before initial wire fracture, additional deformation capacity after initial wire fracture, and aspects of the load-deformation behavior for mono strand-anchor systems. The major finding of their works reveals that the maximum stress and strain capacity of the strands is governed by the brittle fracture of individual strand wire(s) inside the anchor wedges. The fractures occurring at strains as large as 0.04 inch/inch and as small as $0.01 \mathrm{inch/inch} \mathrm{or} \mathrm{less.} \mathrm{Thus,} \mathrm{a} \mathrm{strain} \mathrm{limit} \mathrm{of} 0.01 \mathrm{inch} /$ inch may need to be considered in the design of these structures under seismic loading. Meanwhile, Abramson (2013) conducted studies on the multistrand post-tensioning anchorage systems for seismic resilient rocking wall structures.

Although the rocking system has proven its performance against seismic loads based on numerous laboratory experiments, the bottom corners of the wall remain suffering from local damage in almost previous experimental works. Spalling and crushing of concrete are inevitable at the bottom corners of the walls under cyclic loadings, consequent the loss of tendon force and self-centering capability, and potentially triggering out-of-plane buckling as depicted in Figure 11. The out-of-plane buckling leads the wall to fail in an unstable manner as the entire confined concrete region to the east of panel 1 buckled suddenly as shown in Figure 11 (a). This indicates that high tensile strains developed at the interface between the confined concrete region and the rest of the panel 1, which eventually led to a separation of the confined concrete region as shown in Figure 11(b). As a result, the confined concrete region, which was carrying significant compression, buckled after it was no longer restrained from buckling by the rest of the panel. This failure mode is undesirable as the stability of the wall is jeopardized. 


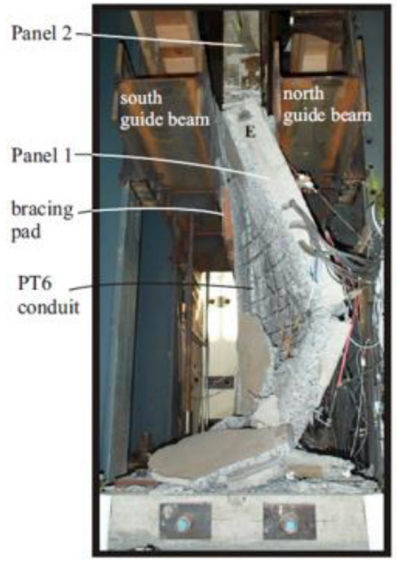

(a)

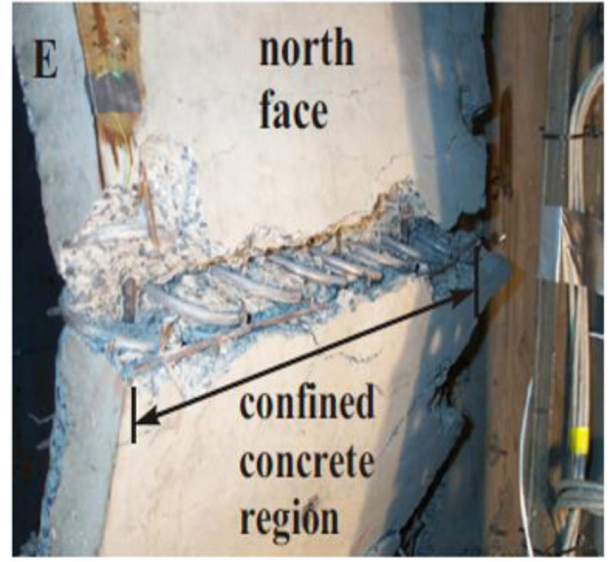

(b)

Figure 11 Unbonded post-tensioned precast concrete wall lateral load testing: (a) out-of-plane buckling failure (b) close-up of north face looking south-west (Perez et. al 2004b).

Such damage is usually difficult to repair and affects the normal use of the structure. In this regard, new types of earthquake-resilient structural walls were developed to improve the seismic performance of structures by introducing the replaceable mechanism at the bottom corners of the wall (instead of using typically confined reinforcement). Guo et al. (2014) have created two steel jackets which were fabricated at the wall toes with concrete cast inside so that the concrete spalling and crushing under high local compressive loads are prevented as shown in Figure 12 (a). Xu et al. (2018) and Xiao et al. (2020) have innovated and applied the two-disc spring devices which exhibit high compression as the replaceable energy dissipation that are symmetrically installed at the two bottom corners of the rocking wall as shown in Figure 12 (b).



(a)


(b)

Figure 12 Configuration of self-centering shear walls installed with (a) steel jacket (Guo et al. 2014) and (b) disc spring (Xu et al. 2018) at wall toes.

Apart from the laboratory experiment, numerous computational works on the static and dynamic performance of rocking walls have been conducted mutually. These computational works are based on analytical and numerical studies. In general, the analytical models of rocking walls can be classified into two categories which are fiber and finite element model. Fiber element model involves structural elements (using line elements) such as beam, truss, and spring elements, which is normally exploited in research-based structural analysis programs such as DRAIN-2DX (Prakash et al. 1993) programs, Ruaumoko 2D (Carr 2007) and OpenSees (Mazzoni et al. 2007). The fiber element model can be adopted to conduct reversed-cyclic and dynamic analyses of the walls. Several research works have been reported (Perez 1998; Kurama 2002; Perez et al. 2004b, 2007; Erkmen and Schultz 2009; Buddika and Wijeyewickrema 2013) concerning analytical model using fiber elements. The other category, which is usually adopted in general-purpose finite elements software packages such as ANSYS (ANSYS, Inc. 2009) and ABAQUS (Hibbitt, Karlsson \& Sorenson 2009). These software packages utilize 2D or 3D elements to model the wall and contact elements to simulate the interaction between the wall and the foundation. The finite element model can also be used for the design of the wall panel as well as to conduct nonlinear pushover analyses. The use of finite element approach on rocking wall studies have been found in many researchers works studies (Hu et al. 2013; Belleri et al. 2014b; Qureshi and Warnitchai 2016; Henry et al. 2016; 
Moharrami \& Koutromanos 2017; Jafari et al. 2017; Dincy 2018). In addition to the two methodologies mentioned above, the numerical analysis approach can also be used to investigate the dynamic behavior of rocking walls subjected to ground excitations. However, this approach is not preferred as it mainly involves mathematical formulations. Hu et al. (2018) and Kalliontzis et al. (2020) are among the researchers who utilize the numerical analysis approach in their works.

Together, some design guidelines, procedures, verification and validation document have been published by researchers on the rocking wall system. These guidelines are purposed to meet the code requirements and develop rational design recommendations needed for broader acceptance of new materials, concepts and technologies for precast concrete construction in different seismic zones. For instance, ACl 318-14 (2014) in Section 18.11.2.2 provisions permit the use of jointed design for special precast walls using unbonded PT by satisfying the requirements of ACI ITG-5.1-07, (2007). Basically, ACI ITG 5.1 is a test validation document, which was established and produced based on a provisional standard and commentary by Hawkins and Ghosh (2004). ACl ITG 5.1 emphases on uncoupled hybrid walls (with the energy dissipating mild steel deformed reinforcement at the wall-to-foundation connection. Meanwhile, the commentary to ACI 318-14 Section 18.11.2.2 refers to ACI-ITG-5.2-09 (2009) is a document for the design of special unbonded PT walls (both uncoupled hybrid walls and coupled walls with the energy dissipating coupling details). Other guidelines and validations on various types of rocking wall systems established can be also obtained (Stanton and Nakaki 2002; Sritharan and Aaleti 2011; Thomas and Sritharan 2004; Aaleti and Sritharan 2009; Smith and Kurama 2014).

In summary, the rocking wall has undergone extensive development in terms of its design and behavior over the last three decades. Beginning with the formation of the rocking concept in the precast wall using the unbonded post-tensioning tendon in the 1990s. The wall system has been improved by incorporating energy dissipation components such as mild steel bars consequent from the low-energy dissipation and large displacements observed in the previous testing. In this respect, the hybrid wall system has been established which is fundamentally designed to attain a stable flag-shaped hysteretic response. Subsequently, various replaceable dissipator mechanisms have been introduced to address the issues on the damage of energy dissipation component aftershock. Typical localized damage observed at the bottom corner of the wall in the rocking wall system has resolved by introducing the devices mounted at both lower corners of the wall. Mutually, the experimental works have been supported by analytical and numerical studies under static and dynamic performance. The elastic and inelastic behavior of prestressing tendon which can cause prestress loss and insufficient deformation capacity during rocking have been also investigated. Apart from that, the design guideline and validation document have been published to satisfy the code requirements. This has led to changes in the relevant governing codes and successful implementations in regions of high seismicity. Despite this success, the connection performance between self-centering shear wall and adjacent structural components such as the floor system and its influence on self-centering ability were found remain being an issue. As a vital component of earthquake-resilient structural systems, the self-centering concrete shear wall system is being developed continuously. Comparatively, the implementation of these wall components into building practice has been limited. This is because much work on rocking wall systems has focused on quasi-static testing of these systems and less effort had been emphasized into investigating the interaction mechanism between rockingwall systems and the surrounding structure. The following sections of this paper reports and discuss the studies that have been conducted on the interaction of rocking wall with surrounding structure.

\section{INTERACTION BETWEEN ROCKING WALL SYSTEMS AND FLOOR DIAPHRAGM}

The rocking systems have been applied variously in the precast structural system. It can be incorporated in the conventional gravity frame structural which creates the self-centering moment-resisting frame or adapted into the precast shear wall in the conventional gravity frame which lead to the formation of rocking wall system. The interaction between the rocking systems to the surrounding structures is crucial. A core component of rocking wall systems is the gap opening mechanism as mentioned in the previous section. This gap opening mechanism allows for nonlinear elastic behavior of the structure. Nevertheless, allowing gaps to form at the base of rocking systems creates connection detailing challenges not only at wall-foundation interface but also at the wall-floor connection region in the entire building story. Transferring load from each floor level to the self-centering wall system is a tricky condition since the shear forces need also to be transferred from the floor diaphragms to the rocking wall in addition to the gravity floor load. When the lateral load is applied to the self-centering wall, intentionally gaps open at the interface between the end of the wall and the foundation face. This has as a consequence a wall uplift which results in local floor damage and may create challenges in connecting the floor system to the rocking wall. Thus, the interaction between the rocking wall systems and surrounding structures especially to the floor is inevitable. Apparently, for the self-centering system, it is insufficient to gain an excellent seismic performance by merely concentrating the rocking behavior at the wall-foundation face. The other part 
of the connection in the building such as wall to floor/column/beam should be taken into consideration. Inline, this section presents the previous works that have been conducted concerning the interaction of rocking wall to the floor diaphragm. However, the number of information that has been reported here is very limited. This is due to the lack of attention that has led to a scarcity of research information in this area. Only a few system tests of rocking-wall structures which include both a rocking-wall system and a surrounding structural system have been conducted to date as summarized in Table 1. This table presents five research works associated with the types of structures used, the types of rocking walls and floor systems adopted, the orientation of the floor system to the walls and the features of the rocking wall to floor connections. Technically, the connection in rocking wall-floor interface can be designed according to three classifications which are rigid, semi-rigid and pinned condition. These three types of precast connection for the wall-floor interface can be achieved depending on how the floor slab is cast (constructed). The rigid, semi-rigid and pinned condition in between precast wall-floor connection are possible to be achieved through traditional cast-in-place floors (CIP), an isolated precast floor system, and in-situ topped precast floor systems respectively. To gain a fully rigid connection, it is required to cast-in-place the floor slab against the wall system as demonstrated in one of the specimens in Liu, (2016) experimental works. Strand and rebar of the CIP slab running through the wall create a rigid connection as shown in Figure 13. This will provide a moment-resisting connection whereby the floor diaphragm would be constrained to deform with the wall system.
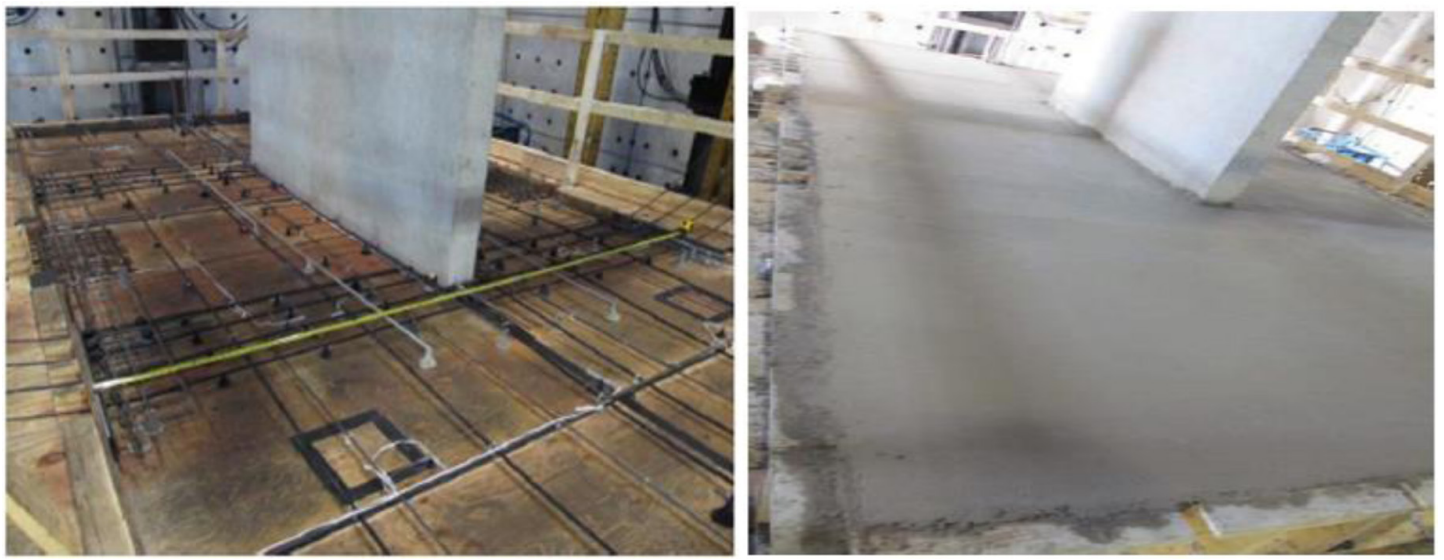

Figure 13 Layout of the reinforcement and strands of the floor slab before and after casting of the specimen (Liu 2016).

An alternative to a cast-in-place connection is to isolate the floor system to the wall element. In this system, the wall is not relied on to carry the vertical gravity loads. The wall-to-floor connection can be designed to transfer lateral inertia loads while leaving the vertical direction free. For instance, Priestley et al. (1999) using a single large bolt in each panel centerline. A steel header beam was installed by using a single large bolt in each panel centerline which runs parallel to the wall as depicted in Figure 14.

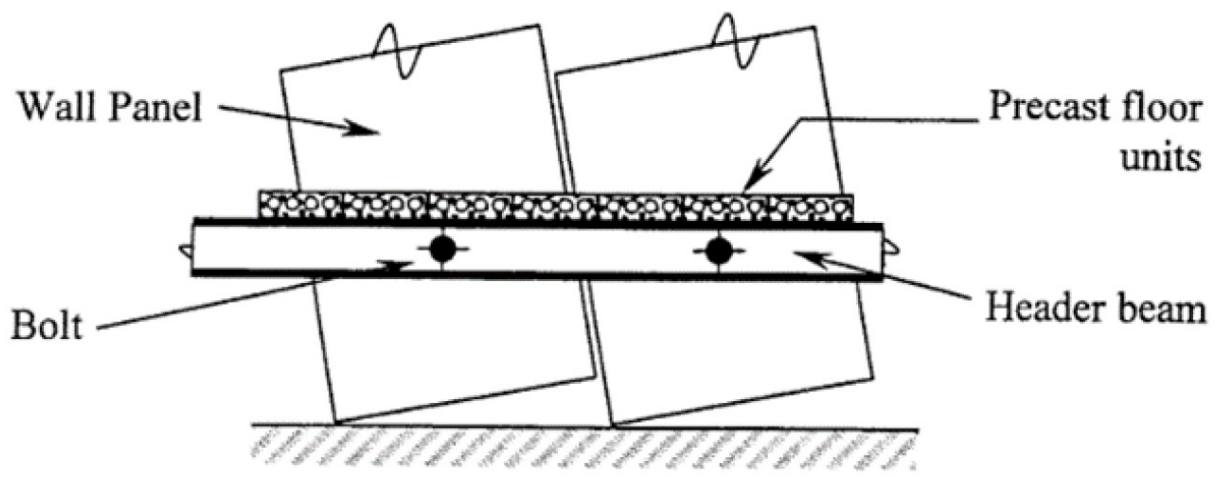

Figure 14 Wall-to-Floor Connection System used in the PRESSS Building (Srithran and Pampanin 2002).

Meanwhile, Schoettler (2010), Henry (2011) and Liu (2016) have adopted a special isolation connection which based on the commercial product. The wall-floor connections in their project were designed to permit free relative vertical movement and free relative rotation by allowing the transfer of horizontal forces from the floors to the wall. Since the 
precast wall does not significantly carry the floor loads, the commercial products have been used as the connection between the rocking wall to the precast floor interface as shown in Figure 15 and 16.



(a)

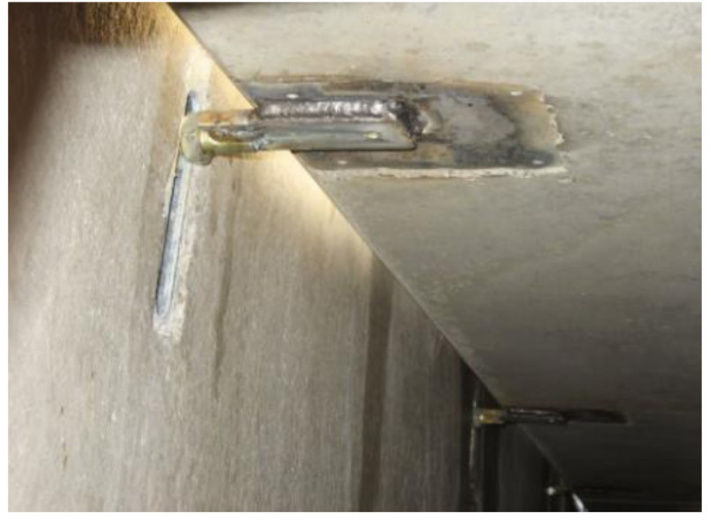

(b)

Figure 15 PSA slotted insert connector by JVI Inc. (a) Schematic diagram (b) Installed PSA slotted insert connector (http://www.jvi-inc.com).

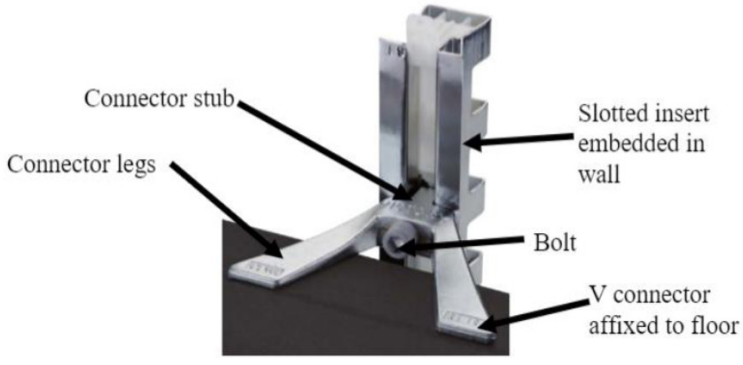

(a)

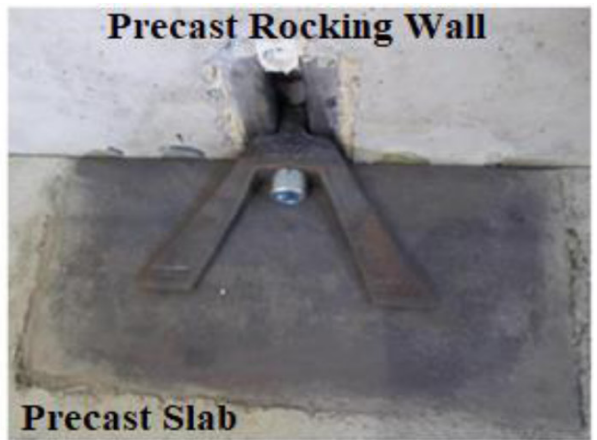

(b)

Figure $16 \mathrm{~V}$ connector and slotted insert by BS Italia; (a) Details diagram (http://www.bs-italia.it/) (b) V connector before welding (Liu 2016).

These special connections would allow the wall and floor to be constrained in the horizontal direction while leaving the wall free to uplift in the vertical direction. This solution could reduce the damage caused to the floor system. According to subassembly tests conducted by Watkins et al. (2014), the connectors can fully isolate the floor if the uplift at the connector location is limited to $25 \mathrm{~mm}$.

If both shear and gravity forces are intentionally transferred from the floor into the wall, the semi-rigid connection is typically used to connect the rocking wall towards the precast floor. This connection type will develop a partial moment resistance through the continuous steel bar embedded horizontally. The precast plank, hollow-core, and double tee flooring systems with in-situ topping are commonly used to gain semi-rigid connection. For instance, Nagae et al. (2011) have used precast double tee slabs with topping as the floor system in the E-Defense project. In this project, a precast half-beam was clamped to the wall panel by a post-tensioned tendon in the wall direction as shown in Figure 17(a). The other half-beam was cast with the topping of the double tee slabs, which formed an indirect wall-slab connection. In the direction perpendicular to the wall plane, multiple inserts pre-embedded in the wall panel were connected to the mesh rebar in the topping of the slab, which formed a direct wall-slab connection as shown in Figure 17(b). The details of the wall-floor connection in out-of-plane and the in-plane direction perpendicular to the wall plane are shown in Figure 18(a) and (b) respectively. 


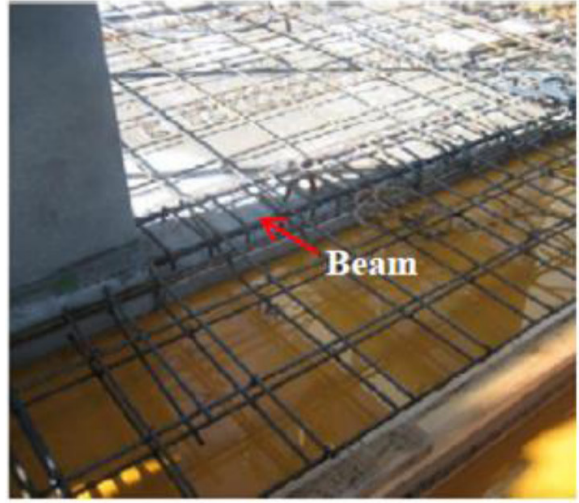

(a)

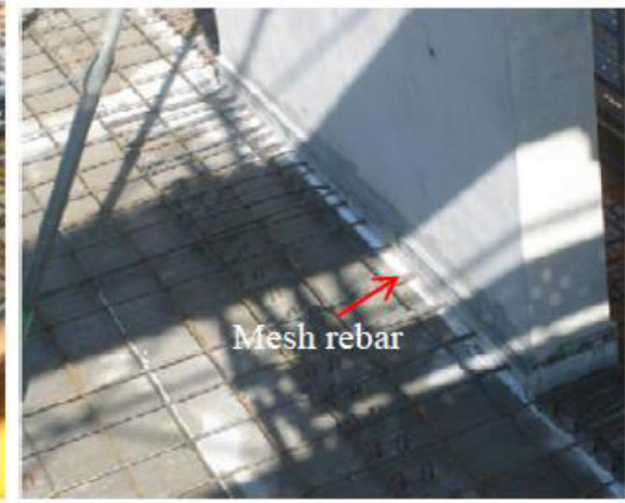

(b)

Figure 17 Site photo of PT wall - floor interface (a) Wall-slab connection in the wall direction (b) Wall-slab connection in the transverse direction (Nagae et al. 2011).

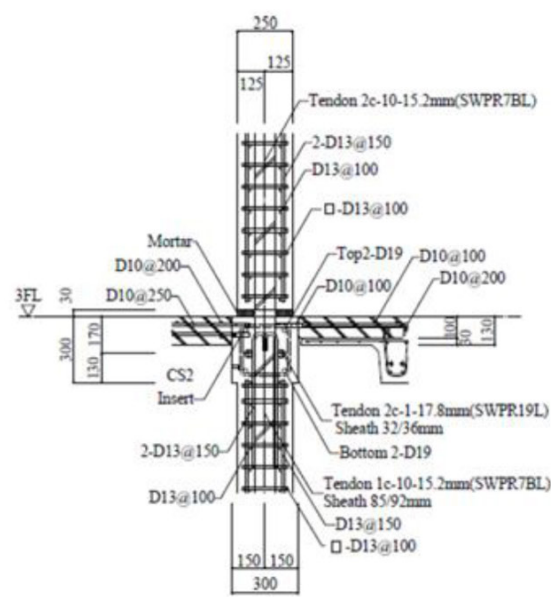

(a)

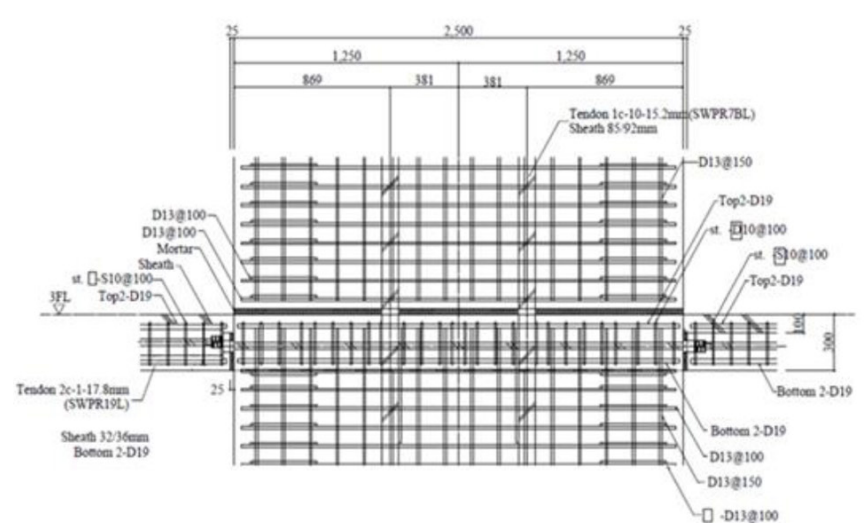

(b)

Figure 18 Detail of PT wall - floor interface; (a) Out-of-plane direction (b) In-plane direction (Nagae et al. 2011).

However, the tendency of surface slipping in between precast half slab and in-situ concrete topping will be higher in the semi-rigid connection. The composite action between old and new concrete surface is vital, especially under seismic condition. Thus, to achieve composite action, horizontal shear stresses must be adequately transferred along with the horizontal interface between the precast half slab and concrete topping slab. The horizontal continuity is gained by the rebar that placed on-site before the concreting of the topping slab as mentioned. The orientation of the precast floor either parallel or bearing against the rocking wall in structural floor plan also influence the interaction behavior between both structural members. If the precast floor is placed parallel towards the rocking wall where the floor ends is supported by a precast frame (usually at precast beam element), only lateral inertia forces will be transferred while the gravitational floor load is mainly distributed to the precast structural frame. Typically, the special isolation connection is used to transfer the inertia forces as demonstrated in Schoettler (2010), Henry (2011) and Liu (2016) project. On the other hand, the bearing orientation of precast floor towards the rocking wall will create significant gravitational floor load transfer to the rocking wall system where the floor damage is inevitable in this condition.

In general, the connection type will determine how the lateral inertia forces from the floor diaphragm are transferred to the wall. The different connection types will exhibit different floors response to vertical displacement of the precast wall. The different response can be observed based on a numerical study of rocking-wall structures that was conducted by Henry (2011) on the four-story prototype building. The floors that cast-in-place to the rocking wall in the first building model were deformed at the wall-floor connections as depicted in Figure 19(a). In contrast, the floors were not affected by the rocking of the wall as shown in Figure 19(b) since the vertical displacement was isolated between the wall and the floors in the second building model. 
Table 1 Summary of Rocking Wall-to-Floor Connection study.

\begin{tabular}{|c|c|c|c|c|c|}
\hline $\begin{array}{c}\text { Project } \\
\text { (Researcher) }\end{array}$ & $\begin{array}{l}\text { Type of } \\
\text { structure }\end{array}$ & $\begin{array}{l}\text { Type of } \\
\text { rocking wall } \\
\text { system }\end{array}$ & flooring system & $\begin{array}{c}\text { Span orientation } \\
\text { of flooring system } \\
\text { to the wall } \\
\text { (Parallel / Bearing } \\
\text { to the wall) }\end{array}$ & $\begin{array}{l}\text { Connection features between } \\
\text { rocking wall-to-floor interface }\end{array}$ \\
\hline $\begin{array}{l}\text { PRESSS Project } \\
\text { (Priestley et al. } \\
\text { 1999) }\end{array}$ & $\begin{array}{l}\text { 0.6-scale of } \\
\text { five stories } \\
\text { frame } \\
\text { structure } \\
\text { with rocking } \\
\text { wall as } \\
\text { lateral } \\
\text { resistance in } \\
\text { the } \\
\text { transverse } \\
\text { direction. }\end{array}$ & $\begin{array}{l}\text { Jointed Wall } \\
\text { system }\end{array}$ & $\begin{array}{l}\text { Two flooring systems were } \\
\text { used: } \\
\text { - the lower three floors were } \\
\text { constructed from pre-topped } \\
\text { double-tees. } \\
\text { - the upper two floors used } \\
\text { hollow-core with a cast-in- } \\
\text { place topping. }\end{array}$ & $\begin{array}{l}\text { Precast floor Units } \\
\text { parallel to the Wall }\end{array}$ & $\begin{array}{c}\text { A steel header beam was installed } \\
\text { (using a single large bolt in each } \\
\text { panel centerline) runs parallel to the } \\
\text { wall. (see Figure } 14 \text { ) }\end{array}$ \\
\hline $\begin{array}{l}\text { Diaphragm } \\
\text { Seismic Design } \\
\text { Methodology } \\
\text { (DSDM) Project } \\
\text { (Schoettler 2010) }\end{array}$ & $\begin{array}{l}\text { Full-scale of } \\
\text { three stories } \\
\text { frame } \\
\text { structure } \\
\text { with rocking } \\
\text { wall as } \\
\text { lateral } \\
\text { resistance in } \\
\text { the } \\
\text { transverse } \\
\text { direction. }\end{array}$ & $\begin{array}{l}\text { Precast } \\
\text { Hybrid Wall }\end{array}$ & $\begin{array}{l}\text { Three flooring systems were } \\
\text { used: } \\
\text {-The first floor: a composite } \\
\text { double tee diaphragm. } \\
\text {-The second-floor level: a non- } \\
\text { composite hollow-core } \\
\text { diaphragm. } \\
\text {-The third floor: A pre-topped } \\
\text { double tee. }\end{array}$ & $\begin{array}{l}\text { Precast floor units } \\
\text { parallel to the Wall }\end{array}$ & $\begin{array}{l}\text { Isolation connection using } \\
\text { commercial product PSA connectors } \\
\text { at the entire floor level. (see } \\
\text { Figure 15) }\end{array}$ \\
\hline $\begin{array}{l}\text { E-Defence } \\
\text { (Nagae et al. } \\
\text { 2011) }\end{array}$ & $\begin{array}{l}\text { Full-scale } \\
\text { four stories } \\
\text { frame } \\
\text { structure } \\
\text { with rocking } \\
\text { wall as } \\
\text { lateral } \\
\text { resistance in } \\
\text { the } \\
\text { transverse } \\
\text { direction. }\end{array}$ & $\begin{array}{l}\text { Precast } \\
\text { Hybrid Wall }\end{array}$ & $\begin{array}{c}\text { Precast double tee slabs with } \\
\text { topping. }\end{array}$ & $\begin{array}{l}\text { Precast floor units } \\
\text { parallel to the wall. }\end{array}$ & $\begin{array}{l}\text { In the wall direction, a precast half- } \\
\text { beam was clamped to the wall panel } \\
\text { by a post-tensioned tendon. } \\
\text { The other half-beam was cast with } \\
\text { the topping of the double tee slabs, } \\
\text { which formed an indirect wall-slab } \\
\text { connection. In the direction } \\
\text { perpendicular to the wall plane, } \\
\text { multiple inserts pre-embedded in the } \\
\text { wall panel were connected to the } \\
\text { mesh rebar in the topping of the } \\
\text { slab, which formed a direct wall-slab } \\
\text { connection. The wall-floor } \\
\text { connection was considered as a } \\
\text { semi-rigid connection (see Figure } 17 \\
\text { and } 18 \text { ). }\end{array}$ \\
\hline $\begin{array}{c}\text { Self-centering } \\
\text { Precast Concrete } \\
\text { Walls for } \\
\text { Buildings in } \\
\text { Regions with Low } \\
\text { to High Seismicity } \\
\text { (Henry 2011) }\end{array}$ & $\begin{array}{l}\text { Full-scale of } \\
\text { two } \\
\text { assemblages } \\
\text { of wall-slab } \\
\text { ABAQUS } \\
\text { models } \\
\text { based Four- } \\
\text { stories } \\
\text { prototype } \\
\text { building. }\end{array}$ & $\begin{array}{l}\text { Precast wall } \\
\text { with end } \\
\text { columns } \\
\text { (PreWEC) }\end{array}$ & $\begin{array}{l}\text { Two flooring systems were } \\
\text { used on a floor: } \\
\text {-The precast floor could be } \\
\text { represented for pre-topped } \\
\text { double-T and hollow-core } \\
\text { units. } \\
\text {-Cast-in-place (CIP) slab }\end{array}$ & $\begin{array}{l}\text { Both precast floor } \\
\text { units and CIP slab } \\
\text { parallel to the wall }\end{array}$ & $\begin{array}{l}\text {-The slotted connector couplings (see } \\
\text { Figure 15) were modelled at four } \\
\text { locations for each wall-to-floor } \\
\text { connection, with two on each side of } \\
\text { the wall. The vertical movement } \\
\text { isolated connections were simulated } \\
\text { by only coupling the horizontal } \\
\text { degree of freedoms of the floors with } \\
\text { those of the wall. } \\
\text {-Rigid wall-floor connections } \\
\text { achieved by considering a cast-in- } \\
\text { place slab. This was simulated by } \\
\text { "embedding" the overlapped portion } \\
\text { of the floors into the wall. }\end{array}$ \\
\hline
\end{tabular}


Table 1 Continued...

\begin{tabular}{|c|c|c|c|c|c|}
\hline $\begin{array}{c}\text { Project } \\
\text { (Researcher) }\end{array}$ & $\begin{array}{l}\text { Type of } \\
\text { structure }\end{array}$ & $\begin{array}{l}\text { Type of } \\
\text { rocking wall } \\
\text { system }\end{array}$ & flooring system & $\begin{array}{l}\text { Span orientation } \\
\text { of flooring system } \\
\text { to the wall } \\
\text { (Parallel / Bearing } \\
\text { to the wall) }\end{array}$ & $\begin{array}{l}\text { Connection features between } \\
\text { rocking wall-to-floor interface }\end{array}$ \\
\hline $\begin{array}{l}\text { Study on } \\
\text { Interaction } \\
\text { between Rocking- } \\
\text { Wall System and } \\
\text { Surrounding } \\
\text { Structure } \\
\text { (Liu 2016) }\end{array}$ & $\begin{array}{l}\text { 1/3-scale of } \\
\text { two } \\
\text { assemblages } \\
\text { of the } \\
\text { specimen } \\
\text { based on six } \\
\text { stories frame } \\
\text { structure } \\
\text { prototype } \\
\text { with rocking } \\
\text { wall as } \\
\text { lateral } \\
\text { resistance in } \\
\text { the } \\
\text { transverse } \\
\text { direction. } \\
\text { (Note: differ } \\
\text { on the } \\
\text { flooring } \\
\text { system used } \\
\text { one another) }\end{array}$ & $\begin{array}{l}\text { Precast wall } \\
\text { with end } \\
\text { columns } \\
\text { (PreWEC) }\end{array}$ & $\begin{array}{l}\text { Two flooring systems were } \\
\text { used: } \\
\text {-Precast hollow core plank for } \\
\text { the first assemblage. } \\
\text {-Cast-in-place (CIP) slab for the } \\
\text { second assemblage }\end{array}$ & $\begin{array}{l}\text {-Precast Floor } \\
\text { Units parallel to } \\
\text { the Wall. } \\
\text {-CIP slab bearing } \\
\text { to the wall. }\end{array}$ & $\begin{array}{l}\text {-Isolation connection using a } \\
\text { commercial product, BS Italia for } \\
\text { precast floor units. (see Figure 16) } \\
\text {-Strand and rebar of the CIP slab } \\
\text { running through the wall create the } \\
\text { rigid connection. (see Figure 13) }\end{array}$ \\
\hline
\end{tabular}

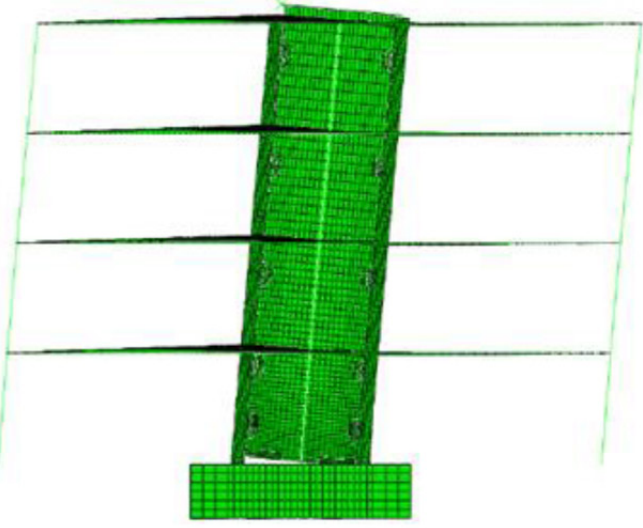

(a)



(b)

Figure 19 Elevation of the calculated displaced shape of the prototype building FEM with (a) First building model: cast-in-place floor (rigid connection) (b) Second building model: precast floor diaphragms (isolated connection) (Henry 2011).

Graphically, the moment resistance of the first building model, which used the rigid wall-floor connections for CIP floor, was significantly increased by approximately 50\% at 3\% drift, compared to that of the "Wall only" for the PreWEC system alone as depicted in Figure 20. On the other hand, the moment resistance of the second building model (isolated floor) was nearly identical to that of the "Wall only" model. 




Figure 20 Base moment versus lateral wall drift response of the three models (Henry 2011).

The simulation results revealed that the responses of rocking wall buildings can be dramatically different because of the use of different wall-floor connections, which generated different wall-floor interaction. The numerical studies conducted by Henry demonstrated that the moment resistances of buildings with rigid wall-floor connections were much higher than those of buildings with vertical movement isolated connections. The moment demands on the floor at the wall-floor connections can be quantified as proposed by Liu (2016)

$M=4 i \alpha+2 i \beta-6 i \frac{-\Delta}{L}=i\left(4 \alpha+2 \beta+6 \frac{w \alpha}{L}\right), i=\frac{E I}{L}$

where $\alpha$ is rotation of the wall; $\beta$ is rotation at the top of the column; $L$ is span of the floor; $\Delta$ is vertical deformation of the floor at the wall end (equal to the wall uplift); $w$ is horizontal distance between the wall-floor connection and the rotation point of the wall; $i$ is effective flexural stiffness of the floor; $E$ is Young's modulus of concrete; I is effective moment of inertia of the floor; and $\mathrm{M}$ is moment at the floor- wall connection. This equation has been derived based on simplified linear elastic two-dimensional (2-D) analytical model as shown in Figure 21.



Figure 21 Simplified 2-D analytical model (Liu 2016).

If the wall-floor interaction is neglected during design, the wall may have a premature failure (e.g., the shear failure and shear sliding). Moreover, the floors with rigid connections are expected to encounter extensive damage according to the analysis. Failure to account for the impact of wall-floor interaction might also result in the loss of the self-centering characteristic of rocking-wall structures, which is one of the most appealing features for this type of structure. In this respect, Liu (2016) has modified Kurama (2005) equation (as shown in Equation 1.0) by accounting for the impact from gravity load transfer path $\left(M_{N}\right)$ and constraint effect from surrounding structure $\left(M_{S}\right)$ despite merely satisfying the relative amount of PT and mild reinforcing steel to achieve the desired self-centering behavior of the rocking wall. A general criterion in determining the steel moment ratio provided by the energy dissipating elements of the rocking wall was proposed as follows

$\frac{M_{P T \_}+M_{N}+M_{W}}{\alpha_{0} M_{E}+\beta_{0} M_{S}} \geq 1$ 
*Note: The denominator is the energy dissipation term in the equation. The numerator is the self-centering term in the equation.

where $M_{P T_{-} i}=$ moment provided by initial effective PT force; $M_{N}=$ moment provided by the gravity loads sustained by the wall (self-weight excluded); $M_{W}=$ moment provided by the self-weight; $\alpha_{0}=$ overstrength factor for the energy dissipating elements; $M_{E}=$ maximum moment provided by the energy dissipating elements; $\beta_{0}=$ overstrength factor for the surrounding structural system; $M_{S}=$ maximum moment provided by surrounding structure.

In summary, there are two general approaches for connecting the floor diaphragm to a rocking wall system: (1) isolating the rocking wall from the floor diaphragm to limit damage effects; and (2) connecting the floor diaphragm to the rocking wall and absorbing local damage. It has been found that it would be arbitrary to claim one type of connection is superior to the other. The practicing engineers are required to evaluate both approaches to make a selection based on the unique conditions associated with each project.

\section{ROCKING WALL SYSTEM IN PRECAST CONCRETE LOAD BEARING STRUCTURES}

The use of rocking wall system instead of the conventional precast wall as lateral load resisting for precast frame structure has offered many advantages, especially on damage avoidance feature. Many previous research works have been focused on the application of rocking wall systems in the precast frame structure since the introduction of the self-centering philosophy of this wall as reported in section 2.0. Likewise, the response of this wall system to the surrounding floor in the precast frame structures has been also investigated as reported in section 3.0. Conversely, there would be a great potential if the similar benefits of the rocking wall system could also be experienced by the precast concrete load-bearing structure. Possibly, the application of the rocking wall systems could offer great performance in the load-bearing structures as recognized in the frame structures system. Fundamentally, the interface response of wall-foundation region in load-bearing structures will not much difference as observed in the precast frame structures. However, the wall-floor joint will probably exhibit a different response to the precast frame structure. The study on this issue has been addressed for the precast concrete frame structures as reported thoroughly in section 3.0. Accordingly, a similar systematic study can be performed to shed light on the response of rock wall system-floor panel interface associated to load-bearing structure and this could be a new branch of research study for rocking wall system. The study is rational to be conducted since this region of connection is susceptible to earthquake loads where certain building structures have reported to collapse due to poor connection details. For instance, a four-story and three-story precast concrete building in Leninakan, Armenia experienced a collapse as shown in Figure 22 (a) and (b) respectively. The failure of precast floor panel has initiated the collapse of this building consequent due to the poor detailed connections between precast floor panels and walls.



(a)

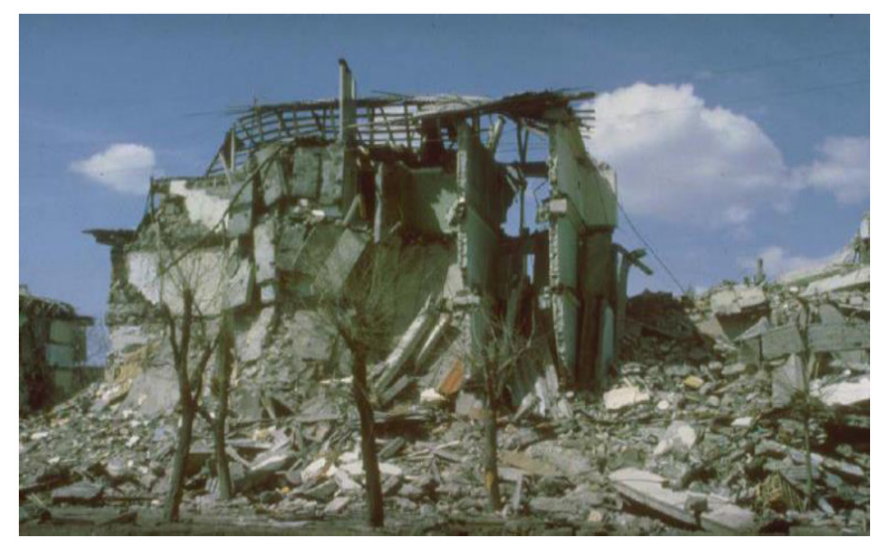

(b)

Figure 22 Collapse of load-bearing structures (a) Damage to a four-story building in Leninakan due to inadequate connection between precast floors and infill walls (b) Collapse of precast floor panels, leaving walls standing in a building in Leninakan ( John A. Martin \& Associates, Inc., 1996).

Principally, the load-bearing structures consist of precast shear wall and floor panel as their main structural systems without the presence of precast beam and column member. The load path of this structural system starts from the 
precast floor panel which then transfers to the shear wall panel and eventually to the foundation and from there to the ground. The lateral forces are resisted by the concrete shear wall panel. Technically, for conventional practice, the precast wall and floor are connected by using the dowel bar and the continuous steel as depicted in Figure 23. The precast slabs are clamped in between the wall elements which lead the negative moments developed. The dowel bar is functioning to join the precast slab, upper and bottom wall and to resist the tensile force developed in the connection. The continuous steel is provided to accommodate the hogging moment in the wet joint of the precast slab. This connection is considered as a semi-rigid connection where the moment-resisting is originated from the friction force, clamping force, continuity steel and top steel in precast floor unit.

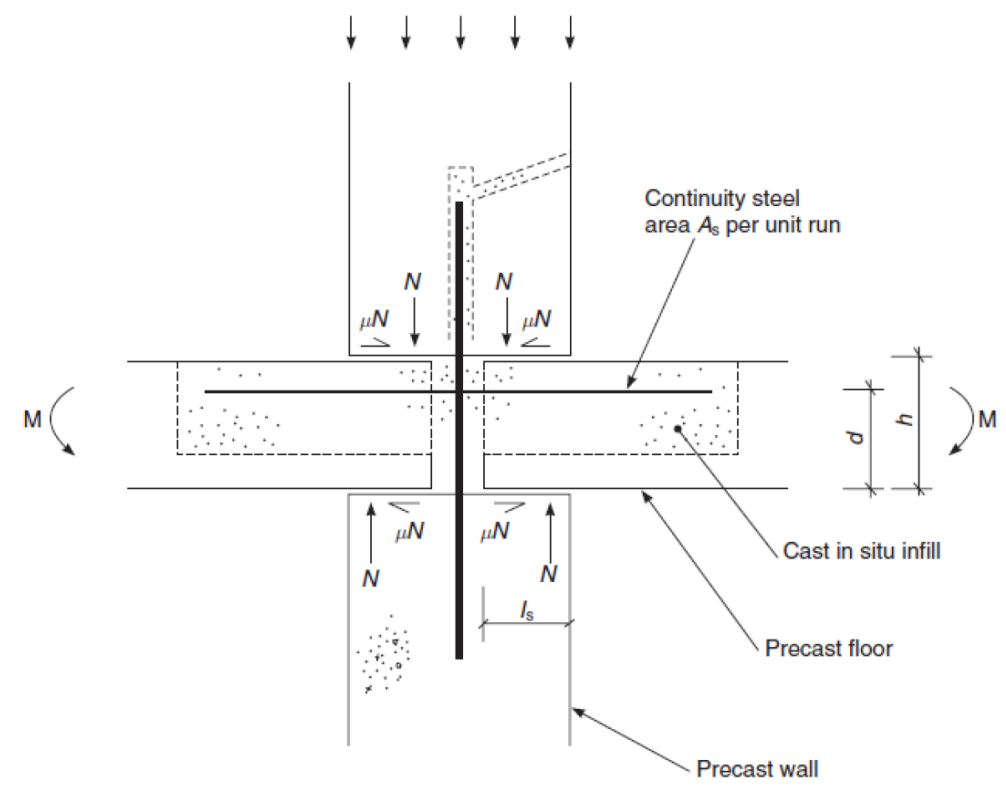

Figure 23 Precast wall-floor connection detail accordance to British code (Elliott 2002).

The monolithic connection is gained by cast-in-situ infill the precast floor connection. The moment capacity of such connection is given by

$M=\mu N h+0.67 l_{s} N+0.95 f_{y} A_{s} 0.8 d$

where $N=$ clamping force, $I_{s}=$ bearing length, $\mu=$ coefficient of friction, $f_{y}=$ yield stress in tie bars of area $A_{s}$, and $d=$ effective depth to tie bars from bearing ledge. This connection type will develop a partial moment resistance through the continuous reinforcement and clamped wall forces consequent differently to a full cast-in-place connection. The research study of the conventional connection subjected to seismic loading has been recorded since the 1960s. The concern on the investigation of the horizontal joint (wall-floor joint) for the conventional precast panel structure under dynamic loads has been embarked since the 1968 "progressive collapse" failure of a precast concrete apartment tower at Ronan Point, England (Pearson and Delatte 2005). This has led to a significant increase in research studies on the large panel structures at that time and much attention has been given to the implementation of special code regulations governing the construction of load-bearing concrete buildings. Previous research studies (Bohdan 1966; Lewicki and Pauw 1972; Backler et al. 1973; Fintel et al. 1976; Sekulovic et al. 1996; Zeck 1976) have concluded that the horizontal joint in precast load-bearing structures is the weakest link in this type of construction under earthquake load. The problem arises from the fact that, unlike cast-in-place concrete structures, non-monolithic construction results from connecting precast panels at the site to form various joints (Harris and lyengar 1980). Numerous research works have been undertaken to study the horizontal connection in precast load-bearing structures under seismic excitation (Hanson 1979; Harris and Abboud 1981; Clough et al. 1989; Lee et al. 1996). Based on these studies, a general conclusion has been derived where the large deformation of the horizontal joints between vertical panels, either slip or particularly rocking, will exert serious deformation demands upon the floor or roof diaphragms. The localized concentration of shear resistance at a vertical steel tie through the joint causes severe damage to the grouted joint portion between the slab ends. Cracking and crushing of the grout disturb shear transfer. 
Similarly, the horizontal joint response under lateral force for precast rocking wall towards the precast floor should be investigated if the self-centering system is to be incorporated into the load-bearing structures. According to research works reported in section 3.0, the main function of the most rocking wall system in those studies is to transfer lateral inertia loads while leaving the vertical direction free. In other words, the rocking wall system has been primarily designed as a lateral resistance for the precast frame structures instead of designing to carry the gravity load from the precast floor. In this respect, the precast floor units were designed to span between the perimeter beams with no intermediate support in the precast frame structure, and so the rocking wall would not be required as a gravity load path. Hence, the wall-to-floor connection could be designed to transfer horizontal inertia loads with unrestrained displacement in the vertical direction. In this regard, most of the precast floor are pinned connection in parallel orientation towards the rocking wall and the special isolation connection was utilized to isolate the vertical displacement of the rocking wall against the precast floor as demonstrated by Schoettler (2010), Henry (2011) and Liu (2016). Unlike the precast frame structures, predominantly, the precast concrete wall in load-bearing structures must take up all the gravity floor load rather transfer the horizontal inertia loads. In this regard, most of the precast floor unit are oriented in load-bearing position in almost situation in the structural floor key plan and elevation as depicted in Figure 24(a) and (b), respectively.



(a) Structural key plan

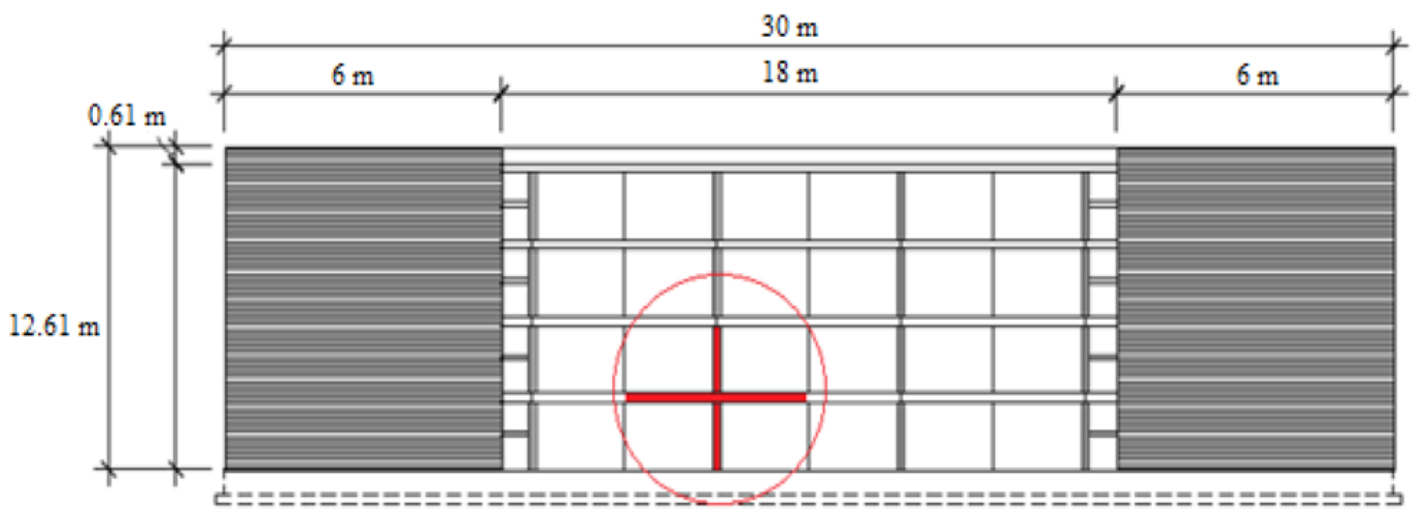

(b) Elevation

Figure 24 Precast concrete load-bearing structures.

Most likely, the adoption of the semi-rigid connection is inevitable if the rocking wall system being used mutually with the precast floor in the precast load-bearing structures. For the precast frame structural, the semi-rigid connection is achieved by using precast half-beam in the wall direction. The precast half-beam is clamped to the wall panel by a post-tensioned tendon while the other half-beam will cast with the topping of the double tee slabs. This detail formed an indirect wall-slab connection as demonstrated (refer Figure 17 and 18) in E-Defense shaking table project conducted by Nagae et al. (2011). Yet, this approach seems not applicable for load-bearing structures since 
the precast beam element does not present as a part of the structural system. An alternative, this could be accomplished either by using precast floor seated on the corbel or L-angle in the load-bearing structures. The traditional practice in the conventional precast wall to floor connection detail has depicted in Figure 23 . This conventional connection design is inappropriate to be adopted for the rocking wall system since the feature of rocking wall system allows only a single gap opening at the wall base joint but not at the upper panel-to-panel joints. Hence, the precast rocking wall system for both single or multiple wall panels can't be simply spliced by the intermediate precast member. In other words, the continuity of the rocking wall panel cannot be violated, otherwise, it is most likely to deteriorate the intended self-centering behavior of the concrete wall. Thus, the precast rocking wall-floor connection design is necessarily proposed differently from the conventional connection. The precast connection system proposed must be simple as possible, practical to be used for onsite installation, cost-effective, capable to accommodate the internal actions developed from the external forces, and satisfy the code requirement. In fact, in accordance to $\mathrm{ACl} 318-14,(2014)$, specifically in section 16.2.1.1 had stated that if two or more connection methods are used to satisfy the requirements for force transfer, their individual load-deformation characteristics should be considered to confirm that the mechanisms work together as intended. The adequacy of connections must be verified by analysis or test as further stated in section 16.2.1.2. In this contribution, the precast concrete rocking wall-floor connection for precast load-bearing structures is proposed and presented as shown in Figure 25.

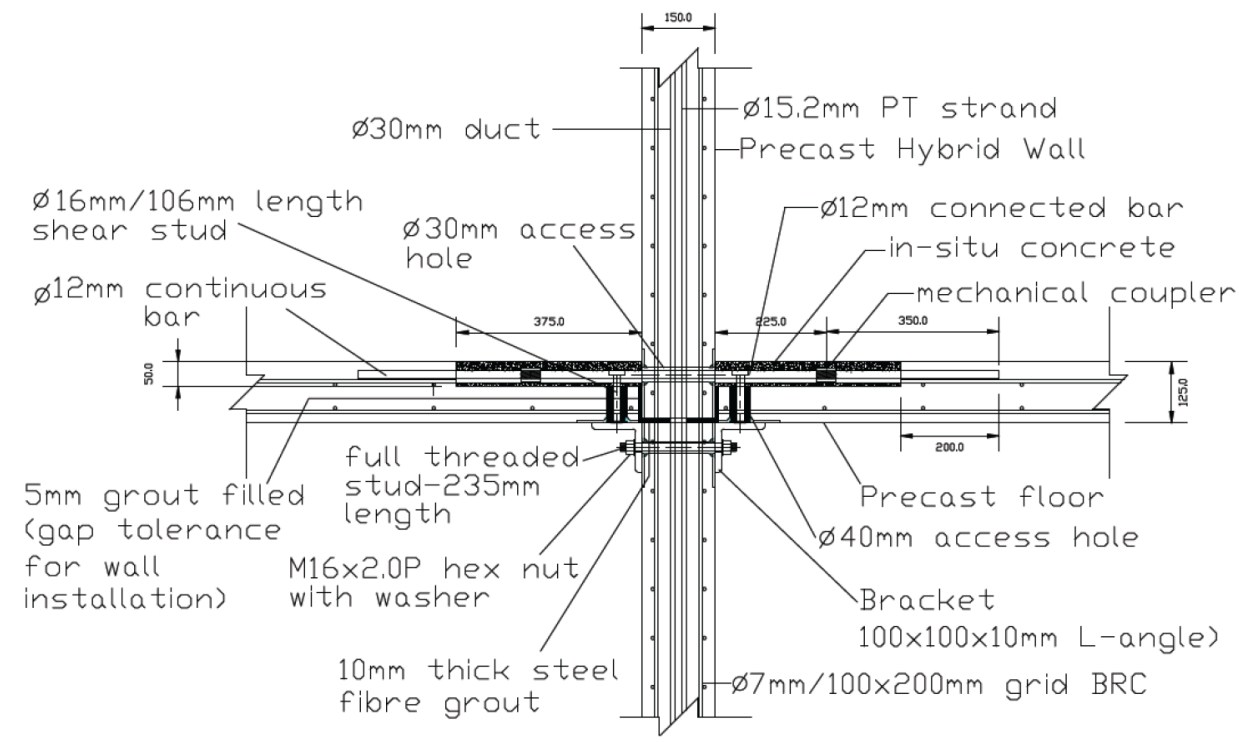

Figure 25 Proposed precast connection detail between the rocking wall system (Hybrid wall type) and precast floor plank. (All unit in mm)

Essentially, the connection system comprised of the seated L-angle steel spot welded by the shear stud, full threaded stud with washer and nut, connected bar and continuous bar which jointed using a mechanical coupler. These multiple components in the connection will produce differences in stiffness, strength and ductility of the components. The L-angle is functioning as the support platform(reaction) for the precast floor unit during the construction stage and being part of the permanent joint for the rocking wall-floor interface during service. The role of the shear stud in the connection is to provide a structural connection between the precast floor and the seated L-angle. This structural connection will distribute any shear forces due to lateral loading and diaphragm action of the slabs that the structure may incur. Besides that, the horizontal forces acting in the plane of the slabs will be also resisted by this shear stud. Without the shear studs in place, there is a slip plane between the precast floor and the seated L-angle. Meanwhile, the moment vector which act at right angles to the main axis of the connection due to flexure of the rocking wall in their plane is resisted by the connected bars and full threaded studs. Similarly, the moment vector which acting parallel to the main axis of the connection due to flexure of the precast floor are also resisted by the connected bars. This particular precast connection detail will form a semi-rigid precast connection. The advantages of this connection are simple for installation, no require special material, able to avoid the interruption of rocking wall panel continuity as illustrated by sub-assemblage of precast wall-floor in Figure 26 and 27. 


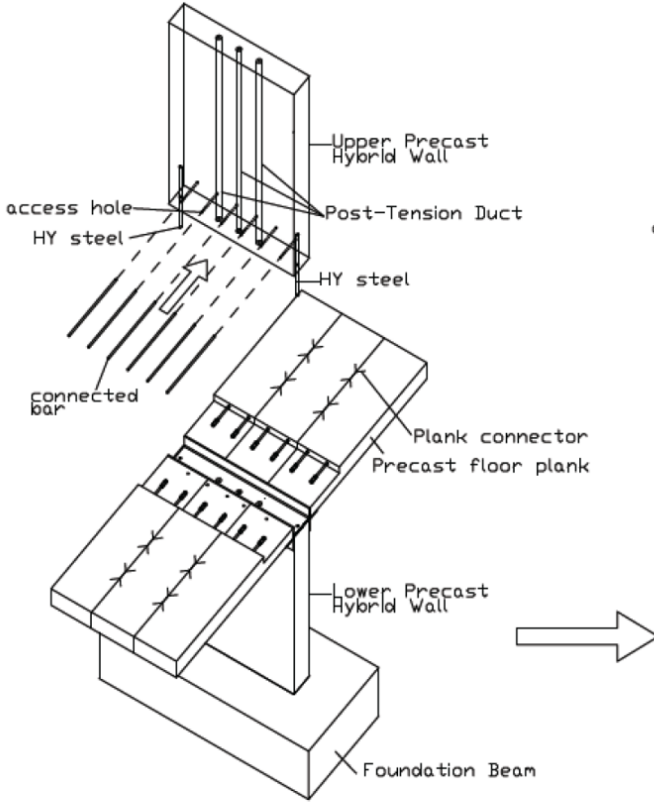

(a)

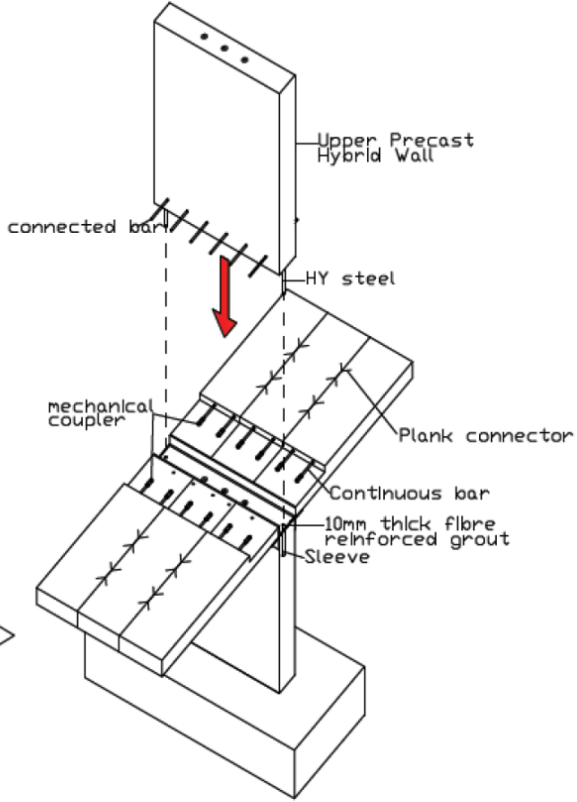

(b)

Figure 26 Erection of the upper wall panel unit (a) slot in the connected bar (b) installing the upper wall panel to the connection.

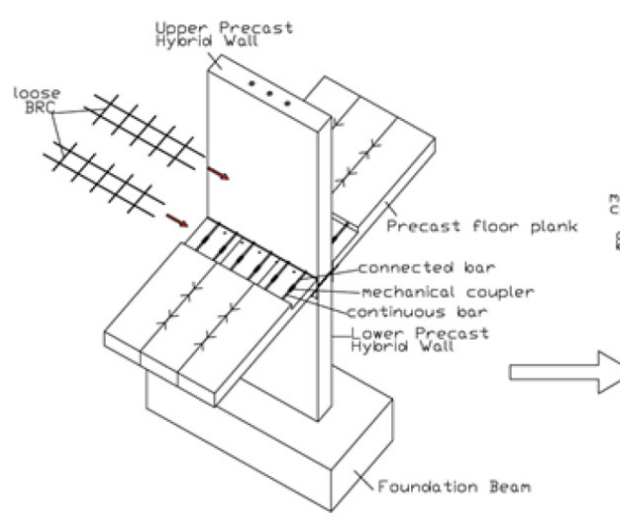

(a)

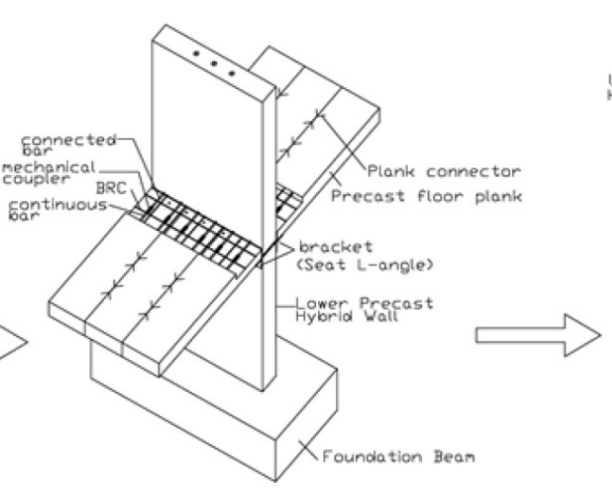

(b)

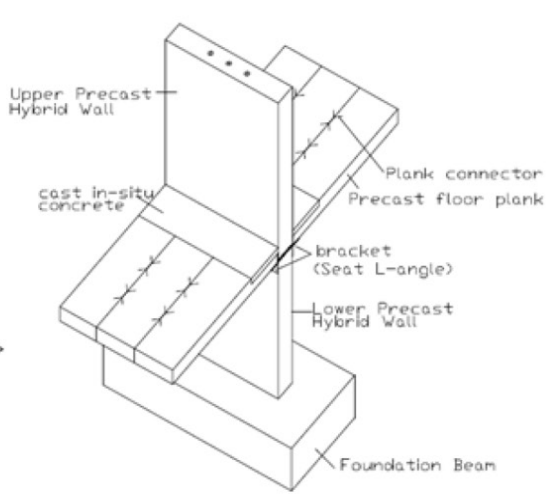

(c)

Figure 27 (a) Jointing the continuous and the connected bars by using the mechanical couplers (b) Placing wire mesh (c) concreting the recess in precast floor plank and tensioning the PT strand.

This sub-assemblage of precast wall-floor connection has extracted from the building plan as highlighted in Figure 24(a). Specifically, it is located at the first-floor level as shown in Figure 24(b). As a standard precast construction, the components will be pre-fabricated, erected and assembled on site. The erection works are started by positioning an approximately $10 \mathrm{~mm}$ thick layer of fiber-reinforced grout at the horizontal joints between wall and foundation beam. This layer is intended for panel alignment and construction tolerance before the installation of the lower panel of the hybrid wall unit. Besides that, this grout pad provides an effective interface material, allowing uniform contact to be achieved with no detrimental effect on wall behavior. Upon pouring the fiber-reinforced grout, erection of the lower precast hybrid wall panel on the foundation beam is executed. The access holes of PT steel and energy dissipator (ED) bars formed during construction in precast wall and foundation beam must be properly aligned during erection. The mild ED bars will be grouted into the foundation using epoxy adhesive. Subsequently, the precast floor is laid down on the steel L-angle which has been bolted earlier on the lower wall panel unit as shown in Figure 26(a). Aforementioned, this L-angle is spot welded with shear stud at certain interval distance to hold in place the precast floor unit at the panel connection. Another $10 \mathrm{~mm}$ layer of fiber-reinforced grout is placed but at the wall to wall panel joint. This is followed by inserting the connected bars into the holes which have been formed earlier on the upper precast wall toe as shown in Figure 26(a). Then, erection of upper panel wall unit is executed as illustrated in Figure 26(b) by ensuring the connected 
bars and the continuous bars are connected parallelly. The continuous bars which have been embedded and protrude from the precast floor are jointed to the connected bar by using the mechanical couplers as depicted in Figure 27(a). The wire mesh or BRC were then inserted into the recessed slab as illustrated in Figure 27(b). The recess in the precast floor is closed by using the cast-in-situ concrete as depicted in Figure 27(c). The concrete was then cured for one to two days before the forms removed. Alternatively, the wire mesh can be replaced by using the steel fiber reinforced concrete. Finally, the PT steel tendon is inserted into the duct and then tensioned by using the jacking machine at the top of the upper wall panel.

In accordance with Europe and Australian standard, every new precast system developed must be tested experimentally and computationally to verify the adequacy of the system to transfer forces between members under seismic loading. The precast design and construction practices are usually supported by the results from experimental investigations in high seismicity countries such as Japan, Canada, Italy, Chile, Mexico, New Zealand and the USA. Moreover, Chapter 21 of ACl 318 (2011) specifies that for seismic regions, "a reinforced concrete structural system not satisfying the requirements of this chapter shall be permitted if it is demonstrated by experimental evidence and analysis that the proposed system will have strength and toughness equal to or exceeding those provided by a comparable monolithic reinforced concrete structure satisfying this chapter." In this respect, the proposed connection needs to be tested for lateral cyclic performance. The in-plane and out-of-plane direction of lateral cyclic loading testing could be possibly performed on the sub-assemblage connection specimen since the rocking wall panels in the load-bearing structures required to resist the lateral load in both planes which are transverse/in-plane and longitudinal/out-of-plane direction as depicted in Figure 28. The load-bearing structures will behave a moment-resisting frame in longitudinal lateral load direction. On the contrary, the shear, tensile and compressive forces will be resisted by the shear wall panels in the transverse direction as depicted in Figure 29. Thus, the interaction study of the rocking wall system towards the precast floor in the load-bearing structures under seismic condition is relevant to be investigated in future.

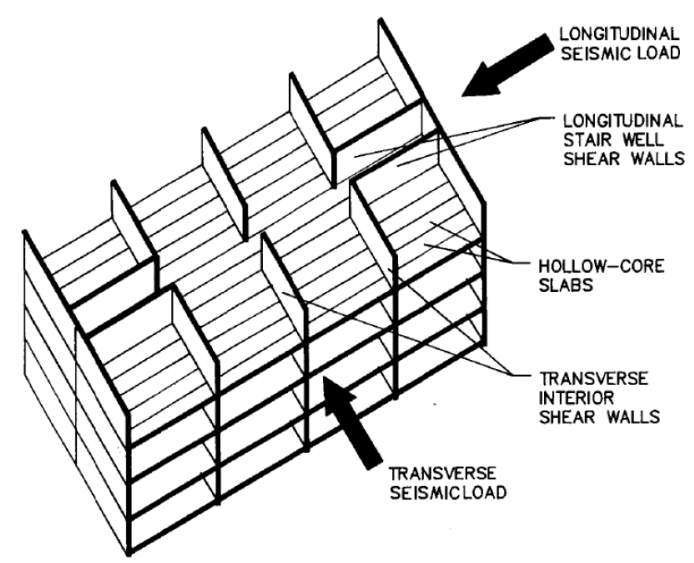

Figure 28 Longitudinal and transverse seismic load on bearing shear wall panel system (fib 2008).

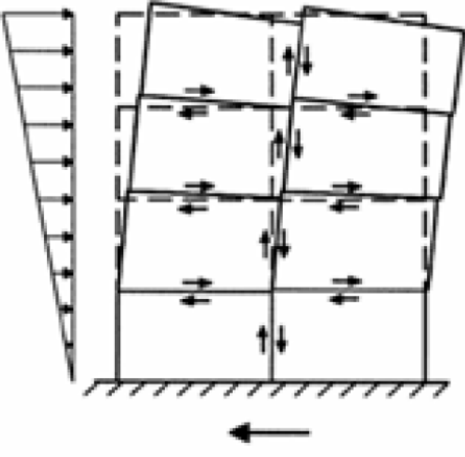

(a)

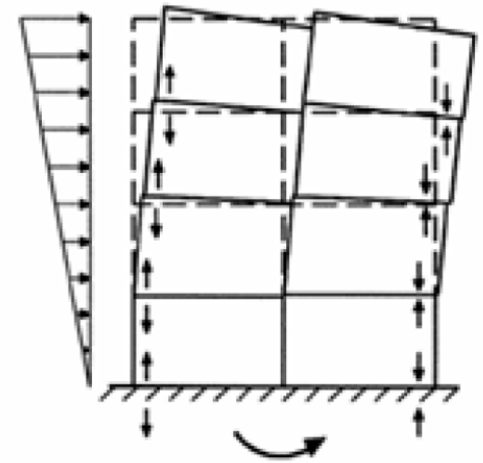

(b)

Figure 29 In-plane action of the prefabricated wall, a) shear forces, b) tensile and compressive forces (fib 2008). 


\title{
5. CONCLUSIONS
}

A substantial amount of research conducted pertaining to precast concrete rocking wall systems has spanned over three decades worldwide. The early stage of this research focused on the development of non-emulative connections between precast structural walls and the foundation. The wall system has shown a self-centering capability and ability to undergo nonlinear lateral displacements with little damage in most of the research studies. Furthermore, the excellent performance of various rocking wall systems has been successfully established and validated throughout the series of experimental and simulation works. Although tremendous research progress has been made towards the use of precast concrete rocking walls in high seismic regions, yet, the acceptance of these wall systems in practice as an alternative for the earthquake resistance in precast structures have not been popularized to date. This has resulted in minimal research works that have been conducted on the interaction between the rocking wall systems and the surrounding floors. Indeed, at present, the general research in the rocking wall systems to floor connection is still in its infancy. Only a few research projects exist that involved experimental testing of building systems using self-centering precast concrete walls as reported in this paper. Perhaps, by enhancing research works on the interaction between rocking wall to the surrounding floor, such an investigation is expected to elevate the confidence of practicing engineers on using these innovative and economical precast structural systems in seismic regions in the future. Previous research works have been focused on the application of rocking wall systems in the precast frame structure since the introduction of jointed connections for critical regions. Moreover, the response of this wall system to the surrounding floor in the precast frame structures has been also investigated. In general, the connection type will determine how the lateral inertia forces from the floor diaphragm are transferred to the wall. The different connection types will exhibit different floors response to the vertical displacement of the precast wall. The connection is critical to the lateral load resistance path. On the other hand, there would be a great potential if the similar benefits of the rocking wall system could be also experienced by the precast concrete load-bearing structure. This benefit is significant and has potential to further extend the use of the selfcentering system in the years to come. In this contribution, the precast concrete rocking wall-floor connection detailing concept for precast load-bearing structures is proposed and presented in this paper. The proposed connection has formed a semi-rigid connection. In-depth experimental studies on the proposed connection for the load-bearing structure need to be implemented. Last but not least, the issues on the rocking wall system responses to surrounding structures should become a new focus and direction of the rocking wall study in the coming years.

\section{Acknowledgments}

The authors would like to thank the Research Management Institute (RMI), University Teknologi MARA Pulau Pinang Malaysia, Halfen Moment Sdn. Bhd., JVI Inc., Industrial Hardware Supply Sdn. Bhd. and the Ministry of Higher Education, Malaysia for the funding [Ref. No Ref. No 600-IRMI/FRGS 5/3 (301/2019)] this research works under Fundamental Research Grant Scheme (FRGS).

Author's Contributions: Conceptualization, MA Masrom; Writing - original draft, MA Masrom; Writing - review and editing, MA Masrom and NH Hamid; Funding acquisition, MA Masrom and NH Hamid; Supervision, NH Hamid.

Editor: Marcílio Alves.

\section{References}

Aaleti, S., Sritharan, S. (2009). A simplified analysis method for characterizing unbonded post-tensioned precast wall systems. Engineering Structures 31:2966-2975. https://doi.org/10.1016/j.engstruct.2009.07.024

\begin{abstract}
Abramson, D. A. (2013). Comprehensive evaluation of multistrand post-tensioning anchorage systems for seismic resilient rocking wall structures, Master Thesis (in United States), University of Minnesota, United States.
\end{abstract}

ACI 318-14. (2014). ACI 318-14: Building Code Requirements for Structural Concrete.

ACl 318-11. (2011). ACl 318-11: Building code requirements for Structural Concrete.

ACI 318-99. (1999). Building Code Requirements for Structural Concrete.

ACl Committee. (2001). Emulating Cast-in-Place Detailing in Precast Concrete Structures. 
ACI ITG-5.1-07. (2007). Acceptance Criteria for Special Unbonded Post-Tensioned Precast Structural Walls Based on Validation Testing and Commentary.

ACI ITG-5.2-09. (2009). Requirements for Design of a Special Unbonded Post-Tensioned Precast Shear Wall Satisfying ACI ITG5.1 (ACI ITG-5.2-09) and Commentary. https://doi.org/10.1038/354361a0

Ajrab, J. J., Pekcan, G., Mander, J. B. (2004). Rocking wall-frame structures with supplemental tendon systems. Journal of Structural Engineering 130: 895-903. https://doi.org/10.1021/jp908242y

ANSYS, Inc. (2009). ANSYS LS-DYNA User's Guide. ANSYS, Inc.

Backler, A. P., Baylik, M., Dill, J. J., (1973). Local Behavior of Shear Transfer and Compression Transfer Joints. The Behavior of Large Panel Structures, CIRIA Report 45, (London).

Belleri, A., Schoettler, M.J., Restrepo, J.I., Fleischman, R. B. (2014a). Dynamic behavior of rocking and hybrid cantilever. ACI Structural Journal 111: 661-671.

Belleri, A., Torquati, M., Riva, P. (2014b). Finite element modeling of rocking walls, Proceedings of the 4th International Conference on Computational Methods in Structural Dynamics and Earthquake Engineering (COMPDYN 2013), $2831-2848$. https://doi.org/10.7712/120113.4706.C1213

Bohdan, L. (1966). Building with Large Prefabricates, Elsevier (New York).

Bruce, T.L., Eatherton, M.R. (2016). Behavior of post-tensioning strand systems subjected to inelastic cyclic loading. Journal of Structural Engineering 142:04016067. https://doi.org/10.1061/(ASCE)ST.1943-541X.0001503

Buddika, H. A. D. S., \& Wijeyewickrema, A. (2013). The behavior of RC rocking wall-frame buildings under pulse-like, Proceedings of the 10th International Conference on Urban Earthquake Engineering.

Carr, A.J. (2007). RUAUMOKO Manual (Volume 2): User Manual for the 2-Dimensional Version Ruaumoko 2D). University of Canterbury, Christchurch, New Zealand.

Clough, R.W., Malhas, F., Oliva, M.G. (1989). Seismic behavior of large panel precast concrete walls: analysis and experiment. PCl Journal 34:42-66. https://doi.org/10.15554/pcij.09011989.42.66

Dincy, P.B. (2018). Analytical study of self-centering reinforced concrete shear walls. International Research Journal of Engineering and Technology (IRJET) 5:5028-5031.

Elliott, K.S. (2002). Precast Concrete Structures, Elsevier (United Kingdom).

Erkmen, B., Schultz, A.E. (2009). Self-centering behavior of unbonded, post-tensioned precast concrete shear walls. Journal of Earthquake Engineering 13:1047-1064. https://doi.org/10.1080/13632460902859136

fib. (2003). Seismic design of precast concrete building structures.

fib. (2008). Structural connections for precast concrete buildings.

Fintel, M., Schultz, D.M., Iqbal, M. (1976). Report 2: Philosophy of Structural Response to Normal and Abnormal Loads, Design and Construction of Large-Panel Concrete Structures, of fire of Policy Development and Research, Department of Housing and Urban Development, (Washington, D.C).

Gavridou, S., Melek, M., \& Wallace, J. W. (2014). Conventional and unbonded post-tensioned lateral force resisting systems - a comparative assessment of expected performance and losses, Proceedings of the 10th U.S. National Conference on Earthquake Engineering. https://doi.org/10.4231/D35M62742

Gu, A., Zhou, Y., Xiao, Y., Li, Q., Qu, G. (2019). Experimental study and parameter analysis on the seismic performance of selfcentering hybrid reinforced concrete shear walls. Soil Dynamics and Earthquake Engineering 116:409-420. https://doi.org/10.1016/j.soildyn.2018.10.003

Guo, T., Zhang, G., Chen, C. (2014). Experimental study on self-centering concrete wall with distributed friction devices. Journal of Earthquake Engineering 18:214-230. https://doi.org/10.1080/13632469.2013.844211

Hanson, N. W. (1979). Seismic Tests of Horizontal Joints. Supplemental Report 'C', Design and Construction of Large Panel Concrete Structures, Office of Policy Development and Research, Department of Housing and Urban Development, (Washington, D.C). 
Harris, H. G., Abboud, B. E. (1981). Cyclic Shear Behavior of Horizontal Joints in Precast Concrete Large Panel Buildings, Proceedings of the Workshop on Design of Prefabricated Concrete Buildings for Earthquake Loads.

Harris, H., lyengar, S. (1980). Full-scale tests on horizontal joints of large panel precast concrete buildings. PCI Journal. https://doi.org/10.15554/pcij.03011980.72.92

Hawkins, N.M., Ghosh, S.K. (2004). Acceptance criteria for special precast concrete structural walls based on validation testing. PCI Journal 49:78-92. https://doi.org/10.15554/pcij.09012004.78.92

Henry, R.S., Sritharan, S., Ingham, J.M. (2016). Finite element analysis of the PreWEC self-centering concrete wall system. Engineering Structures 115:28-41. https://doi.org/10.1016/j.engstruct.2016.02.029

Henry, R.S., Aaleti, S., Sritharan, S., Ingham, J.M. (2008). Design of a shear connector for a new self-centering wall system, Proceedings of the 14th World Conference on Earthquake Engineering.

Henry, R.S. (2011). Self-centering precast concrete walls for buildings in regions with low to high seismicity, Ph.D. Thesis (in New Zealand), The University of Auckland, New Zealand.

Henry, R.S., Sritharan, S., Ingham, J.M. (2011). Recentering requirements for the seismic design of self-centering systems, Proceedings of the 9th Pacific Conference on Earthquake Engineering Building an Earthquake-Resilient Society.

Hibbitt, Karlsson \& Sorenson. (2009). ABAQUS User's Manual - Version 6.9. Hibbitt, Karlsson \& Sorenson, Inc.

Holden, T.J. (2001). A comparison of the seismic performance of precast wall construction: emulation and hybrid approaches, Master Thesis (in New Zealand), University of Canterbury Christchurch, New Zealand.

Holden, T., Restrepo, J., Mander, J.B. (2003). Seismic performance of precast reinforced and prestressed concrete walls. Journal of Structural Engineering 129:286-296. https://doi.org/10.1061/(ASCE)0733-9445(2003)129:3(286)

Hu, X., Li, W.X., Xiang, H., He, H.G. (2013). Study on the analysis model of the self-centering wall. Applied Mechanics and Materials 353-354:1850-1857. https://doi.org/10.4028/www.scientific.net/AMM.353-356.1850

$\mathrm{Hu}, \mathrm{X}$., Lu, Q., Yang, Y. (2018). Rocking response analysis of self-centering walls underground excitations. Mathematical Problems in Engineering 2018:1-12. https://doi.org/10.1155/2018/4371585

Jafari, A., Ghasemi, M.R., Bengar, H.A., Hassani, B. (2017). Modeling of dynamic behavior and estimation of damage incurred by self-centering rocking walls. Journal of Rehabilitation in Civil Engineering 2:93-108.

John A. Martin \& Associates, Inc. (1996). JAMA Website. Retrieved August 4, 2019, from http://www.johnmartin.com/earthquakes/eqshow/

Kalliontzis, D., Schultz, A.E., Sritharan, S. (2020). Generalized dynamic analysis of structural single rocking walls (SRWs). Earthquake Engineering and Structural Dynamics 49:319-338. https://doi.org/10.1002/eqe.3240

Kurama, Y.C., Pessiki, S., Sause, R., Lu, L.W. (1999). Seismic behavior and design of unbonded post-tensioned precast concrete walls. PCI Journal 44:72-89. https://doi.org/10.15554/pcij.05011999.72.89

Kurama, Y.C. (2002). Hybrid post-tensioned precast concrete walls for use in seismic regions. PCI Journal 47:36-59.

Kurama, Y.C. (2000). Seismic design of unbonded post-tensioned precast concrete walls with supplemental viscous damping. ACl Structural Journal 97:648-658.

Kurama, Y.C. (2005). Seismic design of partially post-tensioned precast concrete walls. PCI Journal 50:100-125. https://doi.org/10.15554/pcij.07012005.100.125

Lewicki, B., Pauw, A. (1972). Precast panel buildings,"state of the art report no. planning and design of tall buildings", Proceedings of the International Conference on Planning and Design of Tall Buildings, Lehigh University, Bethlehem, Pennsylvania, 3.

Lee, L.H., Yi, W.H., Seo, S.Y. (1996). Shaking table test of precast concrete wall structure, Proceedings of the 11th World Conference on Earthquake Engineering.

Liu, Q. (2016). Study on interaction between rocking-wall system and surrounding structure, Ph.D. Thesis (in United States), University of Minnesota, United States.

Lu, X., Wu, H. (2017). Study on seismic performance of prestressed precast concrete walls through cyclic lateral loading test. Magazine of Concrete Research 69:878-891. https://doi.org/10.1680/jmacr.16.00363 
Mander, J. B., \& Cheng, C. T. (1997). Seismic resistance of bridge piers based on damage avoidance design. Technical Report NCEER-97-0014, (University at Buffalo, State University of New York).

Marriott, D. J., Pampanin, S., Palermo, A., Bull, D. (2008). Dynamic testing of precast, post-tensioned rocking wall systems with alternative dissipating solutions. The 14th World Conference on Earthquake Engineering 41:90-103.

Mazzoni, S., McKenna, F., Scott, M., Fenves G. (2007). OpenSees Command Language Manual. University of California, Berkeley.

Moharrami, M., Koutromanos, I. (2017). Finite element analysis of damage and failure of reinforced concrete members under earthquake loading. Earthquake Engineering and Structural Dynamics 46:2811-2829. https://doi.org/10.1002/eqe.2932

Nagae, T., Tahara, K., Matsumori, T., Shiohara, H., Kabeyasawa, T., Kono, S., Tuna, Z. (2011). Design and Instrumentation of the 2010 E-Defense Four-Story Reinforced Concrete and Post-Tensioned Concrete Buildings. Technical Report PEER 2011/104, (University of California, Berkeley).

Nakaki, S. D., Stanton, J. F., Sritharan, S. (1999). An overview of the PRESSS five-story precast test building. PCI Journal 44:2639.

Pakiding, L., Pessiki, S., Sause, R., Rivera, M. (2015). Lateral load response of unbonded post-tensioned cast-in-place concrete walls. Structures Congress 1338-1349.

Pampanin, S. (2012). Reality-check and renewed challenges in earthquake engineering: Implementing low-damage systems From theory to practice. Bulletin of the New Zealand Society for Earthquake Engineering 45:137-160. https://doi.org/10.5459/bnzsee.45.4.137-160

Pearson, C., \& Delatte, N. (2005). Ronan point apartment tower collapse and its effect on building codes. Journal of Performance of Constructed Facilities 19:172-177. https://doi.org/10.1061/(ASCE)0887-3828(2005)19:2(172)

Perez, F. J., (1998). Lateral load behavior and design of unbonded post-tensioned precast concrete walls with ductile vertical joint connectors, Master Thesis (in United States), University of Lehigh, United States.

Perez, F.J., Sause, R., Pessiki, S., Lu, L.W. (2002). Lateral load behavior of unbonded post-tensioned precast concrete walls, Proceedings of the International Conference on Advances in Building Technology 1:423-430). https://doi.org/https://doi.org/10.1016/B978-008044100-9/50055-3

Perez, F. J., Pessiki, S., Sause, R. (2004a). Lateral load behavior of unbonded post-tensioned precast concrete walls with vertical joints. PCl Journal 49:48-64. https://doi.org/10.15554/pcij.03012004.48.64

Perez, F. J., Sause, R., Pessiki, S. (2004b). Experimental and Analytical Lateral Load Response of Unbonded Post-Tensioned Precast Concrete Walls. ATLSS Report, No. 04-11(04), 378, (Lehigh University, Pennsylvania).

Perez, F. J., Sause, R., Pessiki, S. (2007). Analytical and experimental lateral load behavior of unbonded posttensioned precast concrete walls. Journal of Structural Engineering 133:1531-1540. https://doi.org/10.1061/(ASCE)0733-

9445(2007)133:11(1531)

Prakash, V., Powell, G., Campbell, S. (1993). “DRAIN-2DX Base Program Description and User Guide; Version 1.10." University of California, Berkeley, Research Report UCB/SEMM-93/17.

Preti, M., \& Giuriani, E. (2012). Full Scale Experimental Investigation on Seismic Structural Walls. In The 15th World Conference on Earthquake Engineering 16: 12790-12798.

Priestley, M.J.N., Tao, J.R. (1993). Seismic response of precast prestressed concrete frames with partially debonded tendons. $\mathrm{PCl}$ Journal 38:58-69.

Priestley, M.J.N. (2002). Direct displacement-based design of precast and prestressed concrete buildings. PCI Journal 1-15.

Priestley, M.J.N. (1991). Overview of PRESSS research program. PCI Journal 36:50-57. https://doi.org/10.15554/pcij.07011991.50.57

Priestley, M. J. N., Sritharan, S., Conley, J. R., Pampanin, S. (1999). Preliminary results and conclusions from the PRESSS fivestory precast concrete test building. PCl Journal 44:42-67. https://doi.org/10.15554/pcij.11011999.42.67

Qureshi, I. M., Warnitchai, P. (2016). Computer modeling of dynamic behavior of rocking wall structures including the impactrelated effects. Advances in Structural Engineering 19: 1245-1261. https://doi.org/10.1177/1369433216642057 
Rahman, A.M., Restrepo, J.I. (2000). Earthquake resistant precast concrete buildings: seismic performance of cantilever walls prestressed using unbonded tendons. Research Report 2000-5. http://hdl.handle.net/10092/10702

Rahman, M. A., Sritharan, S. (2015). Seismic response of precast posttensioned concrete jointed wall systems designed for low-to-midrise buildings using the direct displacement-based approach. PCI Journal 60:38-56.

Restrepo, J. I., Rahman, A. (2007). Seismic performance of self-centering structural walls incorporating energy dissipators. Journal of Structural Engineering 133: 1560-1570. https://doi.org/10.1061/(ASCE)0733-9445(2007)133:11(1560)

Srithran, S., Pampanin, S. (2002). Design Verification, Instrumentation \& Test Procedures. PRESSS Report No. 01/03-09 (Vol. 3), (lowa State University).

Schoettler, M. J. (2010). Seismic demands in precast concrete diaphragms, Ph.D. Thesis (in United States), University of California, San Diego.

Sekulovic, M., Ashkinadze, G., Pujevic, B. S., Salatic, R. M. (1996). Contribution to theoretical and experimental analysis large panel structures subjected to earthquake, Proceedings of the 11th World Conference on Earthquake Engineering.

Sideris, P., Aref, A. J., Filiatrault, A. (2014). Effects of anchorage hardware on the cyclic tensile response of unbonded monostrands. PCl Journal 59:60-77. https://doi.org/10.15554/pcij.06012014.60.77

Smith, B.J., Kurama, Y.C. (2012). Seismic Design Guidelines for Special Hybrid Precast Concrete Shear Walls. Research report NDSE-2012-02, (University of Notre Dame, United States).

Smith, B. J., Kurama, Y. C. (2014). Seismic design guidelines for solid and perforated hybrid precast concrete shear walls. PCI Journal 59:43-59. https://doi.org/10.15554/pcij.06012014.43.59

Smith, B. J., Kurama, Y. C., McGinnis, M. J. (2011). Design and measured behavior of a hybrid precast concrete wall specimen for seismic regions. Journal of Structural Engineering 137:1052-1062. https://doi.org/10.1061/(ASCE)ST.1943-541X.0000327

Smith, B. J., Kurama, Y. C., McGinnis, M. J. (2013). Behavior of precast concrete shear walls for seismic regions: comparison of hybrid and emulative specimens. Journal of Structural Engineering 139: 1917-1927. https://doi.org/10.1061/(ASCE)ST.1943$541 X .0000755$

Sritharan, S., Aaleti, S. (2011). Performance verification of the PreWEC concept and development of seismic design guidelines.

Sritharan, S., Aaleti, S., Henry, R. S., Liu, K.-Y., \& Tsai, K.-C. (2008). Introduction to PreWEC and key results of a proof of concept test. MJ Nigel Priestley Symposium, 95-106.

Sritharan, S., Aaleti, S., Henry, R.S., Liu, K.Y., Tsai, K.C. (2015). Precast concrete wall with end columns (PreWEC) for earthquake resistant design. Earthquake Engineering \& Structural Dynamics 44:2075-2092. https://doi.org/10.1002/eqe.2576

Stanton, J.F., Nakaki, S.D. (2002). Precast Seismic Structural Systems PRESSS (Vol. 3). PRESSS Report No. 01/03-09 (University of Washington, Seattle).

Thomas, D.J., Sritharan, S. (2004). An Evaluation of Seismic Design Guidelines Proposed for Jointed Wall Systems. ISU-ERIAmes Report ERI-04643, (California, United States).

Twigden, K.M., Sritharan, S., Henry, R.S. (2017). Cyclic testing of unbonded post-tensioned concrete wall systems with and without supplemental damping. Engineering Structures 140:406-420. https://doi.org/10.1016/j.engstruct.2017.02.008

Walsh, K.Q., Kurama, Y.C. (2008). Behavior and design of anchorages for unbonded post-tensioning strands in seismic regions. Proceedings of the Structures Congress 314:1-10. https://doi.org/10.1061/41016(314)55

Walsh, K. Q., Kurama, Y. C. (2009). Effects of loading parameters on the behavior of unbonded post-tensioning strand/anchorage systems in seismic regions. Proceedings of the Structures Congress 341:1327-1336. https://doi.org/10.1061/41031(341)145

Watkins, J., Sritharan, S., Henry, R. S. (2014). An experimental investigation of a wall-to-floor connector for self-centering walls, Proceedings of the 10th U.S. National Conference on Earthquake Engineering. https://doi.org/10.4231/D3BZ61862

Weldon, B.D., Kurama, Y.C. (2012). Analytical modeling and design validation of posttensioned precast concrete coupling beams for seismic regions. Journal of Structural Engineering 1:224-234. https://doi.org/10.1061/(ASCE)ST

Weldon, B. D., Kurama, Y.C. (2007). Nonlinear behavior of precast concrete coupling beams under lateral loads. Journal of Structural Engineering 133:1571-1581. https://doi.org/10.1061/(ASCE)0733-9445(2007)133:11(1571) 
Weldon, B.D., Kurama, Y.C. (2010). Experimental evaluation of posttensioned precast concrete coupling beams. Journal of Structural Engineering 136:1066-1077. https://doi.org/10.1061/(ASCE)ST.1943-541X.0000212

Xiao, S., Xu, L., Li, Z. (2020). Design and experimental verification of disc spring devices in self-centering reinforced concrete shear walls. Structural Control and Health Monitoring. https://doi.org/10.1002/stc.2549

Xu, L., Xiao, S., \& Li, Z. (2018). Hysteretic behavior and parametric studies of a self-centering RC wall with disc spring devices. Soil Dynamics and Earthquake Engineering 115:476-488. https://doi.org/10.1016/j.soildyn.2018.09.017

Yang, C., Okumus, P. (2017). Mechanical behavior and prestress loss of unbonded posttension strands in self-centering structures. Journal of Materials in Civil Engineering 29:04017245. https://doi.org/10.1061/(ASCE)MT.1943-5533.0002097

Zeck, U.I. (1976). Seismic Resistance of Precast Concrete Panel Buildings. Report 1: Joints in Large Panel Precast Concrete Structures (MIT Department of Civil Engineering).

Zhu, Z., \& Guo, Z. (2017). Experimental study on emulative hybrid precast concrete shear walls. KSCE Journal of Civil Engineering 21: 329-338. https://doi.org/10.1007/s12205-016-0620-4 